\title{
How geographic and climatic factors affect the adaptation of Douglas-fir provenances to the temperate continental climate zone in Europe
}

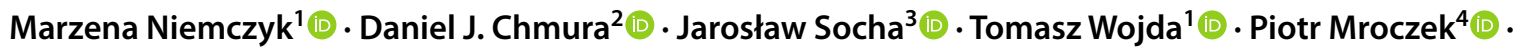 \\ Wojciech Gil ${ }^{1}$ (i) $\cdot$ Barb R. Thomas ${ }^{5}$ (i)
}

Received: 27 January 2021 / Revised: 1 June 2021 / Accepted: 24 June 2021 / Published online: 22 July 2021

(c) The Author(s) 2021

\begin{abstract}
The contribution of Douglas-fir (Df) to European forests is likely to increase as the species is a potential adaptation option to climate change. In this study, we investigated growth and survival of Df seed sources to fill a knowledge gap regarding recommendations for the future use of Df provenances in Poland. Our experimental test site represents the most continental climate among all Df trials installed in the IUFRO 1966-67 test series in Europe. At this unique single site, we evaluated the performance of $46 \mathrm{Df}$ provenances from North America, and nine local landraces of unknown origin. Repeated measurements of tree diameter, height, and volume were analysed, to age 48, representing integrated responses to geographic and climatic conditions. Significant variation in survival and productivity-related traits were found, with the interior Df provenances performing best, in contrast to previous European reports. The higher survivability and volume of the interior provenances resulted from their superior frost resistance. The low precipitation seasonality at the location of seed origin provided an additional advantage to the trees at the test site. Geographic and climatic factors of seed origin explained most of the variation in productivity (77 and 64\%, respectively). The tested landraces exhibited diverse performance, implying that naturalized local seed sources in Poland need improvement and perhaps enrichment with new genetic material from North America, while considering geography and climate. Assisted migration programs should consider the limitations imposed by both frost and drought events in guiding future Df selections for continental climates. Further field testing, early greenhouse screening and DNA testing are also recommended.
\end{abstract}

Keywords Douglas-fir · Provenance trial · Adaptation · Productivity · Climatic factors · Generalized additive models . Landrace

Communicated by Christian Ammer.

Marzena Niemczyk

M.Niemczyk@ibles.waw.pl

1 Department of Silviculture and Forest Tree Genetics, Forest Research Institute, Braci Leśnej 3, Sękocin Stary, 05-090 Raszyn, Poland

2 Laboratory of Genetics and Environmental Interactions, Institute of Dendrology, Polish Academy of Sciences, Parkowa 5, 62-035 Kórnik, Poland

3 Department of Biometry and Forest Productivity, University of Agriculture, Al. 29 Listopada 46, 31-425, Krakow, Poland

4 Department of Geomatics, Forest Research Institute, Braci Leśnej 3, Sękocin Stary, 05-090 Raszyn, Poland

5 Department of Renewable Resources, 442 Earth Sciences Building, University of Alberta, Edmonton, AB T6G 2E3, Canada

\section{Introduction}

With ongoing climate change occurring at a speed far exceeding the natural adaptive abilities of forest trees (Davis and Shaw 2001; Nathan et al. 2011), forestry faces new challenges in the context of afforestation and possible changes in species composition of forest stands (Allen et al. 2010). These challenges put the long-term provenance experiments carried out around the world in a new light, providing new information to support matching provenances with projected future climates for assisted migration programs (Wang et al. 2006, 2010; Rousi et al. 2012).

The growth and survival of trees at specific sites or regions depend on their adaptive capacity and plasticity (Kijowska-Oberc et al. 2020). Population-specific responses to climate and other factors are usually examined in common 
garden experiments, where the adaptability is assessed on the basis of survival rate and the phenotypic traits of primary interest for forestry, such as tree height and diameter. Historically, the main objective of such studies was to evaluate populations within a species and select those which are best adapted, productive and resistant to biotic and abiotic stresses (White et al. 2007). However, many provenance tests have been revisited to assess these populations' adaptive ability to specific climatic conditions and climate change in particular (Matyas 1994; Schmidtling 1994; Andalo et al. 2005; Aitken et al. 2008; Chakraborty et al. 2015, 2016). Long-term provenance experiments are best suited to achieve this goal, combined with a rapidly changing climate, the empirical results available from these transplant studies can support successful programs geared at assisted migration or assisted colonization of introduced forest tree species (moving planting material outside their natural range) (Aitken and Whitlock 2013).

Douglas-fir (Pseudotsuga menziesii (Mirb.) Franco)) (Df), a conifer native to North America, is a prime example of a tree species of global importance to forestry. With the two major geographic varieties - the coastal or green type $P$. menziesii var. menziesii, and the interior, Rocky Mountain, or blue type P. menziesii var. glauca - Df spans an enormous geographic range in western North America (Hermann and Lavender 1999). Due to its superior productivity, wood quality, and high market value (Krakowski and Stoehr 2009), Df has been introduced into many countries around the world (Chakraborty et al. 2015) including those in Europe where the species has been planted since the early nineteenth century (Lavender and Hermann 2014; van Loo and Dobrowolska 2020). At present, Df plantations occupy more than 823,534 hectares in 35 European countries, which accounts for $0.4 \%$ of the European forest area (Bastien et al. 2013; Konnert and Bastien 2019). This area represents the largest planting of any non-native forest-forming tree species in several European countries, including Germany, France and Poland (Barzdajn 2013; van Loo and Dobrowolska 2020).

Due to the importance of Df for forestry, the genetic variation in this species has been investigated in numerous provenance trials in North America, Europe and elsewhere. Having evolved in highly heterogeneous environments, Df exhibits large intraspecific variation in many phenotypic traits (St Clair and Howe 2007; Krakowski and Stoehr 2009; Leites et al. 2012; Rehfeldt et al. 2014; Bansal et al. 2015; St Clair et al. 2020). Thus, the response to specific climatic conditions, when moved to new regions, may vary among populations. To obtain a better understanding of the potential of this species, in 1966-67, the International Union of Forest Research Organizations (IUFRO) carried out a systematic and representative collection of seed, covering the entire natural range of the species. In this experiment, 182 provenances of Pseudotsuga were tested throughout 36 countries worldwide (Kleinschmit and Bastien 1992; Bastien et al. 2013; Konnert and Bastien 2019), including Poland, where over 100 provenances have been studied (Mejnartowicz 1976; Burzyński 1990).

Introduction of Df to Poland (within its current borders), as in many other European countries (e.g. Germany, the Netherlands), began long before these IUFRO collections were made and the first systematic provenance trials were established (Barzdajn 2013). Df was introduced to Poland in 1830 (Burzyński 1990; Kleinschmit and Bastien 1992; Chylarecki 2004) with a large increase in area planted to Df from 1895-1945, thanks to the activities of prof. Schwappach, and following the encouraging results of those introductions (Barzdajn 2013). Those early plantings of Df, resulted in the existence of well-adapted mature stands today (Chylarecki 2004), although the parental origin of these stands remains unclear. These long established stands have now naturalized to the Polish landscape, forming local landraces (Zobel and Talbert 1984), making them a potential ideal source of seed for future use.

Early observations of provenance trials from the 1966-67 IUFRO Df collection established in Poland, enriched by progeny from the populations previously introduced to Poland (now local landraces), has allowed for early recognition of both frost resistance and survival rate in selected provenances (Burzyński 1990). The early results of height growth from 120 experimental plots established throughout Europe, including the Polish trials, were also included in the retrospective study on Df adaptation potential (exclusively IUFRO seed collections) under the current and projected future climates in Europe (Isaac-Renton et al. 2014). However, the provenance performance models developed had a weaker predictive power for Central Europe (referred to as Eastern Europe in Isaac-Renton et al. (2014)), with a more continental climate (Poland), than for most of the other sites studied (Isaac-Renton et al. 2014). The lack of sufficiently accurate prediction power of these models, in terms of the growth potential of specific Df provenances at more continental sites, and the fact that the relative performance of provenances may vary through time, prompted the undertaking of more detailed research focused exclusively on Polish conditions.

Df is considered a 'winner species' for Central Europe according to species distribution models under projected climate change scenarios (Dyderski et al. 2018) and its contribution to forests in Europe is likely to increase in the future. Df may be considered as an alternative to some native, highly productive conifer species (e.g. Norway spruce), whose decline is observed in many regions in Central Europe. The importance of Df for Polish forestry is shown through its inclusion in the "Program of conserving forest genetic resources and breeding of trees in Poland for the years 2011-2035" (Chałupka et al. 2011). However, there 
are still no official recommendations regarding the use of Df provenances in Poland. Furthermore, few attempts have been made to relate the climatic conditions of the seed sources to those of the proposed deployment areas, or to test for local adaptation and effects of provenance transfers, especially to continental climatic conditions (Mejnartowicz 1976; Burzyński 1990).

The aim of this study was to analyse the effect of geographical location and climatic conditions of Df origin, on its survival, growth rate and productivity in a long-term provenance trial established in eastern Poland. This trial represents the most continental climatic conditions among all of the lowland trial sites from the IUFRO 1966-67 Df trial series installed in Europe. Seedlots from the local landraces were also included in this eastern Polish trial to evaluate their productivity and usefulness as potential seed sources for the country. Results of this study may support decisions regarding seed transfer and limitations to assisted migration of $\mathrm{Df}$ in future forest practices.

\section{Materials and methods}

\section{Provenance trial}

The experimental area of the eastern Polish trial (Rudka) site was established in 1974 in the Rudka Forest District. This area is located in the lowland part of Poland $\left(52^{\circ} 41^{\prime} 33^{\prime \prime} \mathrm{N}, 22^{\circ} 42^{\prime} 32^{\prime \prime} \mathrm{E}\right)$, with a prevailing temperate continental climate, representative for eastern Poland, i.e. the right-bank of Poland in the middle reaches of the Vistula River. This location was also the most continental (climatically severe) lowland test site established in Europe during the IUFRO Df campaign. The average long-term (1982-2012) temperature of the coldest month (January) was $-5.0{ }^{\circ} \mathrm{C}$ (extreme temperature recorded $-35^{\circ} \mathrm{C}$ ), the average temperature of the warmest month (July) was $17.3{ }^{\circ} \mathrm{C}$, and the average annual precipitation was $574 \mathrm{~mm}$ (Fig. 1).

The Rudka experimental test site was selected to estimate survival, frost resistance and productivity of Df provenances under suboptimal climatic conditions outside the Df planting zone in Europe. Frost hardiness was tested in $1978 / 79$ during the juvenile development stage and was described in detail by Burzyński (1990).

Fifty-five seedlots of Df were included in the 1974 provenance trial with 38 seedlots originating from seeds collected during the 1966-67 IUFRO campaign - 12 provenances from the northern part of the species range in British Columbia (BC), Canada, 23 from Washington (WA) State and three from Oregon (OR) State, USA. In addition, eight operational seedlots were also collected in WA and included in the experiment (Fig. 2; Table 1). The Concrete provenance (WA) is represented by both seeds from the IUFRO collection (No. 16, Fig. 2), and from a commercial collection (No 14, Fig. 2). Overall, the experiment represents 35 seedlots from the coastal native range of Df and nine from the interior geographic range in western North America (Fig. 2).
Fig. 1 Long-term (1982-2012) average monthly temperatures (+ maximal/-minimal, red bars) and average sum of precipitation for the studied region (Białystok meteorological station)

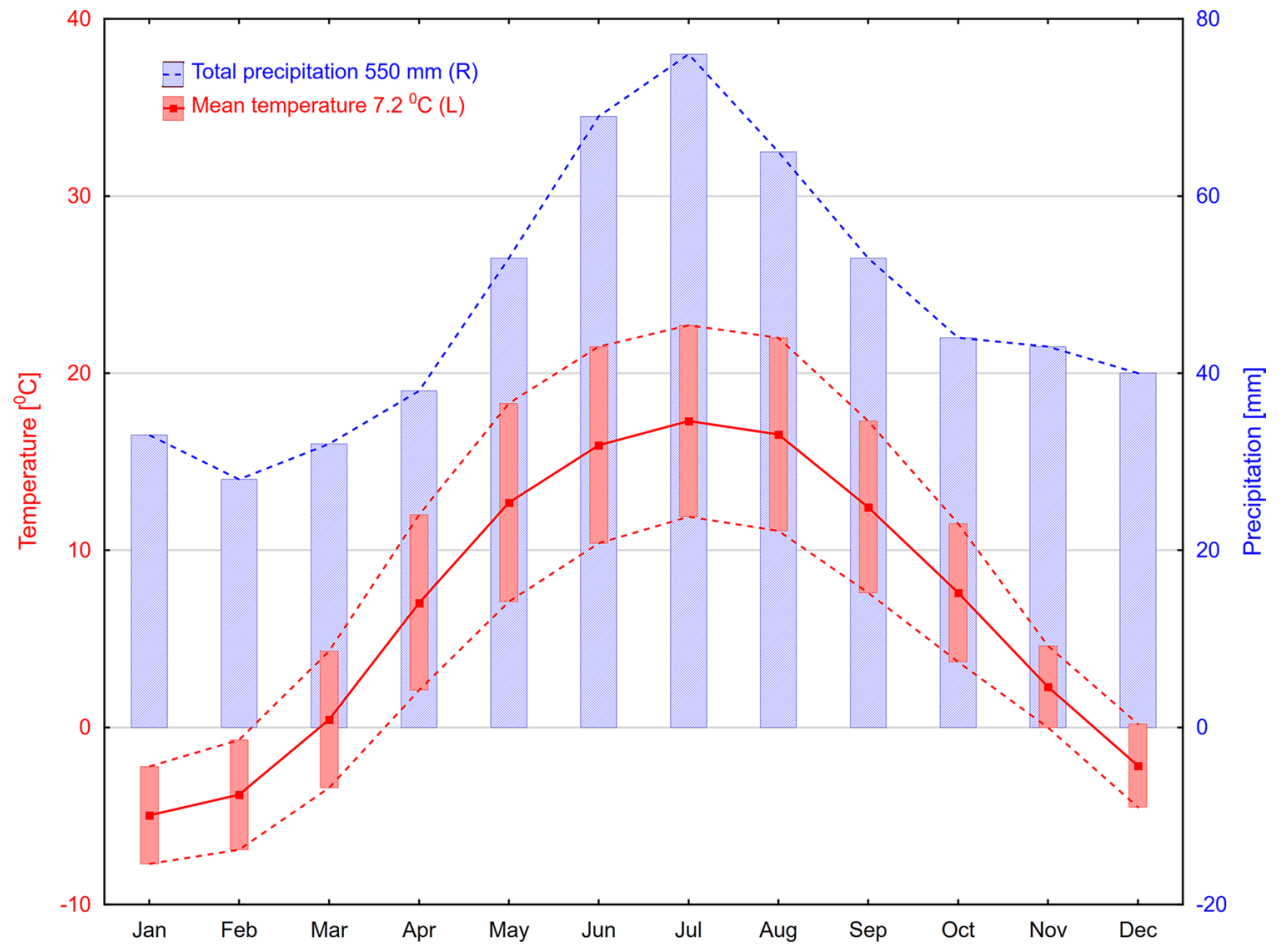




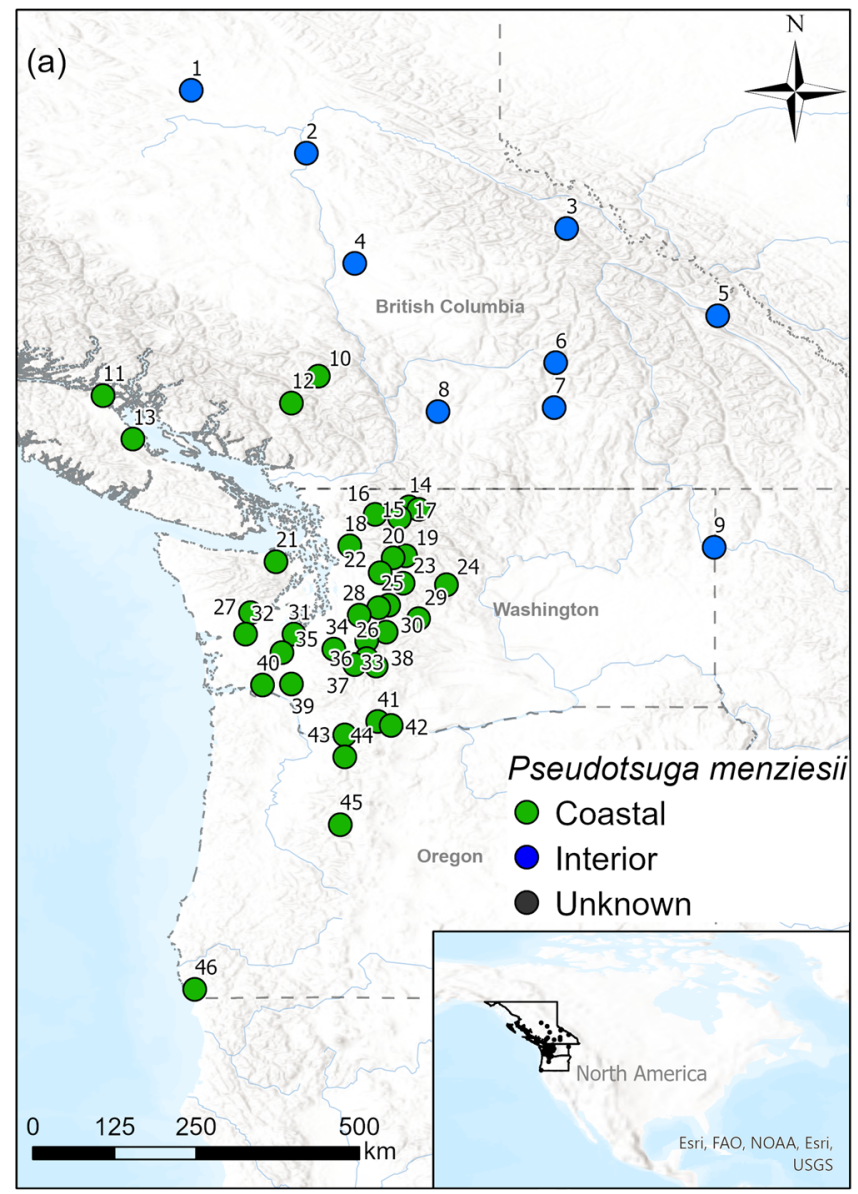

Fig. 2 The locations of tested Douglas-fir provenances. The blue dots show the location of the interior Douglas-fir provenances; in latitudinal gradient (from north to south) provenances (a - North America); (b-Poland). The red dots show the location of the coastal Douglas-

The progeny from nine previously established Df stands (now landraces), from unknown origins (Berney 1972; Hintsteiner et al. 2018) were also included in this provenance trial (Fig. 2). However, on the basis of cone and seed characteristics, it appears that stands located in Ujsoły and Pokrzywno correspond to coastal BC Df populations from the zone between $50^{\circ}$ and $52^{\circ} \mathrm{N}$ (Berney 1972), while stands located in Biedrusko, Wirty and Dębno correspond to the interior Df variety (Burzyński 1990; Chylarecki 2004) (Fig. 2). We refer to those populations as landraces, although the concept of a landrace is broader and involves evolutionary adaptation of progeny to the new environment of introduction (Casañas et al. 2017). The introductions made to Poland have performed well, acclimating to the climatic conditions of their introduced location during $>80$ years of growth (Burzyński 1990). Because conifer landrace populations may form quickly from the parent to offspring generation in new environments (Saxe et al. 2001), including seed from the landrace sources in our study provided a unique opportunity to

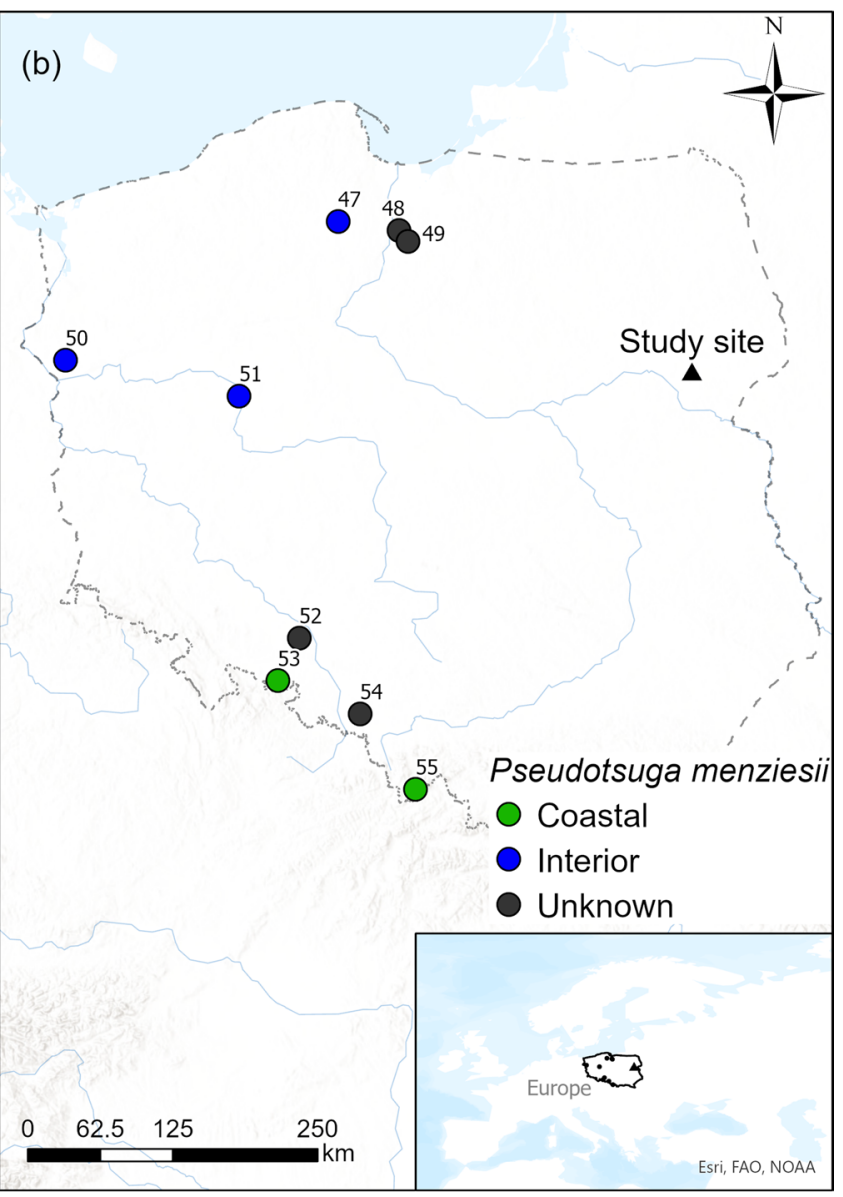

fir provenances. The black dots (b in Poland) indicate landraces of unknown origin. The black triangle shows the location of the trial site (Rudka) in Poland

compare the performance of the progeny with the original provenances from the IUFRO collection and determine the suitability of these landraces as a future seed source.

The study layout was a completely randomized design (CRD) with 55 seedlots in 26-46 replications, depending on a varying number of seedlings available for planting.

Planting material was sown in the spring of 1970 and grown for four years at the Chojnów forest nursery, in Poland. A total of 1953 four-year-old seedlings were planted at the Rudka trial site at a $2 \times 2 \mathrm{~m}$ spacing. The soil at the planting site was classified as a brown podsolic (Burzyński 1990). No thinnings were carried out over the 44 year trial.

\section{Measurements}

Diameter at breast height (DBH; at $1.3 \mathrm{~m}$ ) was measured on all living trees in 2005 (age $36 \mathrm{y}$ ); 2014 (45 y) and 2017 (age $48 \mathrm{y}$ ). In 2014 height $(\mathrm{H})$ of all trees were measured while in 


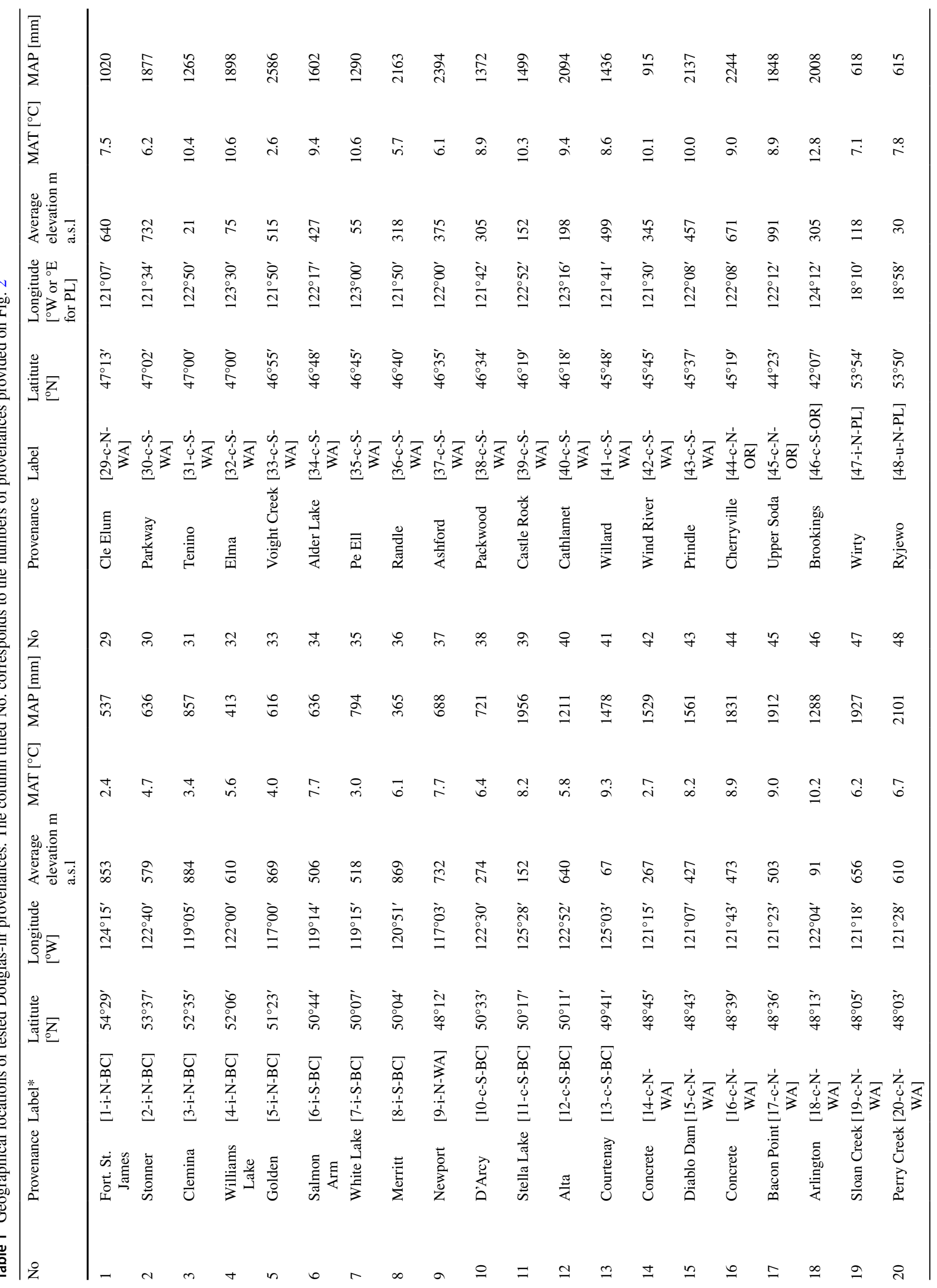




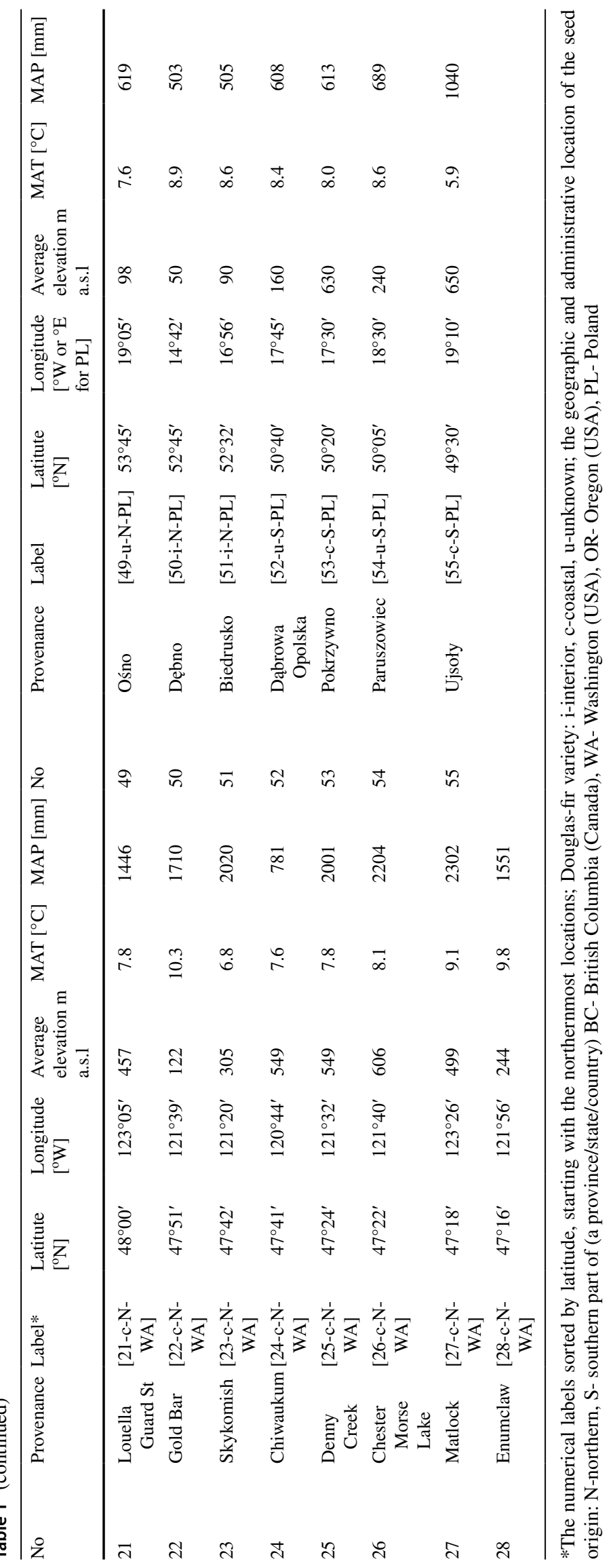


2017 only $20 \%$ of trees were recorded $(\mathrm{H})$ and 30 trees were randomly selected and harvested for the purpose of crosssectional measurements. For harvested trees the diameters were taken with a caliper in the middle of $1 \mathrm{~m}$-long sections from the bottom to the top of a tree to calculate individual tree volumes using the sectional method $(\mathrm{V})$.

\section{Data analysis}

For trees that were not measured for $\mathrm{H}$ in 2017, the height curve was fitted using the Näslund function (Näslund 1936):

$H=\left(\frac{D B H}{\alpha+\beta * D B H}\right)^{2}+1.3$,

where $\mathrm{H}$ represents tree height (m), DBH is the diameter at breast height $(\mathrm{cm})$, and $\alpha, \beta$ are the fitted parameters.

We were concerned that standard volume equations available in the literature for $P$. menziesii might not be adequate enough for data obtained in this study; therefore, to develop a volume equation for the trees in our study, we used allometric functions commonly used in tree biomass and volume modelling (Sit and Poulin-Costello 1994) (we used Eq. 2 for measurements taken in 2014 (age 45 y) and 2017 (age 48 y), and Eq. 3 for measurements carried out in 2005 (age 36 y)):

$$
\begin{aligned}
& \log _{10}(V)=\beta_{0}+\beta_{1} * \log _{10}(D B H)+\beta_{2} \log _{10}(H) \\
& \log _{10}(V)=\beta_{0}+\beta_{1} \cdot \log _{10}(D B H)
\end{aligned}
$$

The parameters of these functions were fitted based on the individual tree volumes $(\mathrm{V})$ obtained from the sectional measurement data. The parameters of Eqs. 2 and 3 and goodness of fit statistics for the allometric equations are listed in Table 2. The estimated parameters were then used in allometric functions to estimate the volume of all remaining individual trees for each provenance parameterized for a given age, using the measured $\mathrm{DBH}$ and $\mathrm{H}$ obtained from direct measurements (in 2014) or the height curve (in 2017). Stand productivity expressed as volume per hectare $\left(\mathrm{V}_{\mathrm{ha}}\right)$ was calculated using individual tree volumes for a given provenance taking its survival (S) into account. Mean annual increment of volume (MAI) was assessed as a $\mathrm{V}_{\mathrm{ha}}$ for a given provenance divided by the final time point of our experiment, age 48 .

To assess changes in the productivity of different provenances over time, which may be important in light of the recent accelerating climate change, we additionally estimated the periodic annual increment (PAI). Productivity of provenances was compared over two time intervals. The first interval was estimated based on $\mathrm{V}_{\mathrm{ha}}$ at age 36 (time interval 1970-2005), and corresponded to PAI between 0 and 36 years. The second time interval estimated productivity from 2005 to 2017, reflecting the current climate, and was calculated as the change in volume per ha of a given provenance between age 36 and 48, divided by the number of years designated as the growing period (12 years) (Avery and Burkhart 2015):

$P A I=\frac{V_{h a 2}-V_{h a 1}}{T_{2}-T_{1}}$

where $V_{h a}$ is the volume per area unit at times 1 and 2 and $T_{1}$ represents the year starting the growth period, and $T_{2}$ is the end year.

\section{Geographic and climatic data}

Adaptation and the formation of local ecotypes/varieties through natural selection, gene flow, and other evolutionary processes are the outcome of long-term interactions between environmental conditions and local populations (Kawecki and Ebert 2004). Thus, to capture the environmental conditions under which Df provenances evolved, each provenance was characterized by geographic coordinates and bioclimatic factors. Geographic variables were used to represent constant, climate-determining factors (Molga 1986) that approximate genetic adaptation to local climate based on a longer time frame than modern climate data allows for. Geographic variables included latitude, elevation of seed origin, and longitude. Longitude, in our study, described the proximity to the ocean among seed sources from Df's native range in North America and was used to nuance differences between coastal and interior varieties (Table 1).

Bioclimatic variables which change more rapidly, especially during current climate change were in turn used to generate more biologically meaningful variables derived from monthly temperature and precipitation values (Läderach 2011). Climate conditions of the population origin were obtained from the WorldClim database (Fick and Hijmans 2017). Each population was characterized by the 19 bioclimatic variables representing long-term mean values. The dataset was obtained for the baseline period 1950-2000, which is available in the WorldClim database (Fick and Hijmans 2017). The bioclimatic variables represented annual trends (e.g., mean annual temperature, annual precipitation), seasonality (e.g., annual range in temperature and precipitation), and extreme or limiting environmental factors (e.g., temperature of the coldest and warmest month and precipitation of the wettest and driest quarter) (Läderach 2011; Fick and Hijmans 2017).

For clarity, we refer hereafter to each seed source tested in our study by the provenance name and provide the numerical labels sorted by latitude, starting with the northernmost locations. Each label also provides information on the 
Table 2 Fitted coefficients of two volume equations for Douglas-fir

\begin{tabular}{llllllrlrrr}
\hline Equation & $\mathrm{R}^{2 *}$ & MSE & RMSE & CV [\%] & Parameter & Estimate & SE & $-95 \%$ CI & $+95 \%$ CI & $p$ \\
\hline 2 & \multirow{2}{*}{0.997} & 0.001 & \multirow{2}{*}{0.038} & 0.121 & $\mathrm{~b}_{0}$ & -4.306 & 0.126 & -4.575 & -4.036 & $<0.001$ \\
& & & & & $\mathrm{~b}_{1}$ & 2.008 & 0.146 & 1.697 & 2.320 & $<0.001$ \\
& & & & & $\mathrm{~b}_{2}$ & 0.872 & 0.230 & 0.381 & 1.363 & 0.002 \\
3 & \multirow{2}{*}{0.989} & \multirow{2}{*}{0.002} & \multirow{2}{*}{0.052} & 0.286 & $\mathrm{~b}_{0}$ & -3.896 & 0.089 & -4.084 & -3.708 & $<0.001$ \\
& & & & & $\mathrm{~b}_{1}$ & 2.530 & 0.066 & 2.390 & 2.671 & $<0.001$ \\
\hline
\end{tabular}

${ }^{*} R^{2}$ coefficient of determination, MSE mean squered error of the estimate, $R M S E$ root mean squared error, $C V$ coefficient of variation, $S E$ standard error, $C I$ confidence intervals

geographic Df variety (interior (i)/coastal (c)/unknown (u)) and the geographic and administrative location of the seed origin, i.e., northern $(\mathrm{N})$ or southern $(\mathrm{S})$ part of a province/ state/country (British Columbia (BC), Washington (WA), Oregon (OR), Poland (PL)). For example, the provenance White Lake is labelled as [7-i-S-BC] (number 7 on the map, Df interior type, southern British Columbia), which is consistent with the map numbers on Fig. 2 and data presented in Table 1. In general, labels numbered 1-9 refer to seed sources of Df interior type (i), while numbers 10-46 refer to the Df coastal variety (c) from the native range in North America. Numbers 47-55 refer to Polish landraces (Fig. 2, Table 1).

\section{Statistical analysis}

Analysis of variance (ANOVA) was used to test for variation among examined provenances in mean $\mathrm{DBH}, \mathrm{H}$ and $\mathrm{V}$. The mathematical model for the single factor completely randomized design was applied, according to the following equation:

$x_{i j}=\mu+\alpha_{i}+\varepsilon_{i j}$

where $x_{i j}$ is a dependent variable, $\mu$ represents mean value of the dependent variable, $\alpha_{i}$ is an effect of provenance, $\varepsilon_{i j}$ represents random error.

When the ANOVA indicated a significant provenance effect, the Tukey's HSD test was used $(\alpha=0.05)$ to test for differences in mean values among provenances.

To compare the rank order of provenances in PAI between the two time intervals considered, i.e. PAI between 1970-2005 and PAI between 2005-2017, we computed the nonparametric statistics: the Kendall rank correlation coefficient and Spearman's Rank Correlation Coefficient. Before conducting the analysis, the PAI data expressed in a quantitative scale was scaled up to ordinal data.

To further explore the dataset and classify the provenances according to their similarity/distance, cluster analysis was used based on the standardized data obtained for individual tree $\mathrm{V}$ and $\mathrm{S}$. The Euclidean distance was used as a distance metric, and the Unweighted Pair Grouping Method with Arithmetic-mean (UPGMA) was chosen as a clustering criterion. The UPGMA is one of the most commonly used variants of the Globally Closest Pair clustering algorithm, defining the dissimilarity between clusters as their average dissimilarity (Gronau and Moran 2007).

The relationships between $\mathrm{DBH}, \mathrm{H}, \mathrm{V}_{\mathrm{ha}}$ and $\mathrm{S}$ and the predictor geographic and climatic variables were modelled using the generalized additive models (GAM, Eq. 6) (Hastie and Tibshirani 1990), which is a non-parametric extension of the generalized linear models (GLM). We chose this statistical approach because it enables exploration of the shapes of response curves for Df provenances to environmental gradients and allows fitting of statistical models that are in better agreement with ecological theory (Frescino et al. 2001; Austin 2002; Lehmann et al. 2002; Guisan et al. 2006; Aertsen et al. 2010). GAM uses transformation procedures that are independent for each predictor variable, which are summed to calculate the response variable according to the equation (Guisan and Zimmermann 2000):

$\mathrm{G}(\mathrm{E}(\mathrm{Y}))=\beta+f_{1}\left(\mathrm{X}_{1}\right)+f_{2}\left(\mathrm{X}_{2}\right)+f_{3}\left(\mathrm{X}_{3}\right)+f_{n}\left(\mathrm{X}_{\mathrm{n}}\right)$

where $\mathrm{Y}$ is the dependent variable, $\left(\mathrm{X}_{\mathrm{i}}\right)$ are the predictor variables, $(\mathrm{G})$ is the link function, $f_{1}, f_{2}, \ldots f_{n}$ are smoothing spline functions estimated from the data, $\beta$ is the free term. An identity link function was specified for the normally distributed response data. Predictor variables entered the models individually using a smoothing spline with four degrees of freedom. The optimal amount of smoothing was estimated based on cross-validation. The geographic and climatic trends were modelled separately. The predictor variables in the geographic models were latitude, longitude and elevation of the provenance origin in the natural range of Df. The local landraces were excluded from the model for geographic data. All 19 bioclimatic characteristics were taken into account in the climatic models. To determine the importance of bioclimatic variables and establish the final set of predictors for modeling, we applied the method to determine the importance of variables using the $\mathrm{R}$ language 
package VIP (R Core Team, 2020). VIP is a general framework for constructing variable importance plots from various types of models in R.

Aside from some standard model-specific variable importance measures, VIP also provides model agnostic approaches, which include: 1) an efficient permutationbased variable importance measure, 2) variable importance based on Shapley values (Štrumbelj and Kononenko 2014), and 3) the variance-based approach (Greenwell et al. 2018). The selection of the best model, i.e. the model containing independent variables which explained the largest amount of observed variance, was based on the adjusted coefficient of determination/model efficiency $\left(\mathrm{R}^{2}\right.$ adj $)$. Graphs of smoothing spline functions of GAM models were used to illustrate the effect of individual predictor variables on dependent variables. Homoscedasticity of the model was analysed using a scatterplot of the standardized residuals against each of the independent variables. The statistical analyses were performed using the statistical package Statistica 13 (StatSoft Inc.).

\section{Results}

\section{Survival rate}

The survival rate at the Rudka trial site was highly variable between Df provenances (Fig. 3, Table 3). At age 36, the average survival was $42 \%$ with the highest survival observed for the provenances from Newport [9-i-N-WA] (91\%), Cle Elum [29-c-N-WA] (89\%), White Lake [7-i-S-BC] (89\%), Golden [5-i-N-BC] (86\%) and Wirty [47-i-N-PL] (86\%). All provenances with the highest survival except for Cle Elum represented the interior variety of Df. On the other hand, the coastal provenances from more southern locations: Pe Ell [35-c-S-WA] and Cathlamet [40-c-S-WA], Brookings [46-c-S-OR], as well as Ujsoły [55-c-S-PL] and Dąbrowa Opolska [52-u-S-PL], had a survival rate below $10 \%$. At age 48 the overall survival rate at the study site dropped to $22 \%$, with 13 provenances experiencing $100 \%$ mortality. At the last assessment the highest survival rate was recorded for the provenances from Wirty [47-i-N-PL] (75\%), White Lake [7-i-S-BC] (71\%) and Salmon Arm [6-i-S-BC] (69\%, Fig. 3, Table 3), all representing the interior variety of Df.

\section{Productivity-related characteristics}

All biometric traits we measured at the Rudka site varied significantly within the provenances examined (Table 3 ). The mean DBH at age 36 years ranged from $4.6 \mathrm{~cm}$ for Packwood [38-c-S-WA], to $24 \mathrm{~cm}$ for Biedrusko [51-i-N-PL], a local landrace. At age 36 the Biedrusko landrace also had the largest individual tree stem volume, which was significantly greater than for all other provenances.

At age 48, the Biedrusko landrace maintained its dominant position for $\mathrm{DBH}, \mathrm{H}$ and individual stem $\mathrm{V}$. The other provenances with stem volumes above the average were: White Lake [7-i-S-BC] and Salmon Arm [6-i-S-BC] from the continental, interior part of $\mathrm{BC}$, Bacon Point [17-c-NWA], Skykomish [23-c-N-WA] and Matlock [27-c-N-WA] from WA, and Wirty [47-i-N-PL] in Poland (Table 3).

Taking into account the survival, the mean stand volume at age 36 was $120 \mathrm{~m}^{3} \mathrm{ha}^{-1}$. The largest volume was recorded for the White Lake [7-i-S-BC] $\left(623 \mathrm{~m}^{3} \mathrm{ha}^{-1}\right)$, Wirty [47-i-N-PL] $\left(564 \mathrm{~m}^{3} \mathrm{ha}^{-1}\right)$ and Salmon Arm [6-i-SBC] $\left(545 \mathrm{~m}^{3} \mathrm{ha}^{-1}\right)$ provenances (Fig. 4). These three provenances maintained their high productivity, and by age 48 stand volume reached 1216; 952; and $1112 \mathrm{~m}^{3} \mathrm{ha}^{-1}$ respectively (White Lake, Wirty, Salmon Arm), while the average volume for all provenances combined did not exceed $280 \mathrm{~m}^{3} \mathrm{ha}^{-1}$. Figure 5 illustrates the geographic pattern of variation among the studied populations for stand volume. It is clear that seed sources from coastal BC, WA, and west of the Cascades showed the poorest performance. The only two provenances from those regions with a $\mathrm{V}_{\mathrm{ha}}$ above the average were Bacon Point [17-c-N-WA] and Chester Morse Lake [26-c-N-WA] (Figs. 4 and 5). All other populations with an above-average $\mathrm{V}_{\mathrm{ha}}$ at age 48 were from interior $\mathrm{BC}$ and WA or east of the Cascades, and the Polish landraces originating from the interior variety (Figs. 4 and 5).

The volume per unit area measurements provided MAI values calculated at the final time point of our experiment, age 48. The average $\mathrm{MAI}_{48}$ was $4.41 \mathrm{~m}^{3} \mathrm{ha}^{-1} \mathrm{yr}^{-1}$, while the best performing provenances, White Lake [7-i-S-BC] and Salmon Arm [6-i-S-BC], attained an $\mathrm{MAI}_{48}$ of 25.34 and $23.16 \mathrm{~m}^{3} \mathrm{ha}^{-1} \mathrm{yr}^{-1}$, respectively (Fig. 4). The changes in annual volume increment were also considerable between the two time intervals considered. The first time interval covered the younger stages of tree growth, at age 0-36 years, while the second time interval referred to the high pole stand stage, within the range of $36-48$ years. The average $\mathrm{PAI}_{0-36}$ for the provenances tested was $3.33 \mathrm{~m}^{3} \mathrm{ha}^{-1} \mathrm{yr}^{-1}$, while the average $\mathrm{PAI}_{36-48}$ reached $7.65 \mathrm{~m}^{3} \mathrm{ha}^{-1} \mathrm{yr}^{-1}$ and coincided with the period of intensive volume increment. The $\mathrm{PAI}_{36-48}$ for the provenances with the greatest productivity, White Lake and Salmon Arm, reached exceptional growth rates of 49.34 and $47.02 \mathrm{~m}^{3} \mathrm{ha}^{-1} \mathrm{yr}^{-1}$, respectively, indicating a continuous increase in their annual volume increment and successful competition with neighbouring trees, reinforcing their dominant positions in the stand (Fig. 4). In general, the Spearman's rank correlation coefficient $(0.853, p<0.001)$, and the Kendall's tau coefficient $(0.648, p<0.001)$ indicated a significant association between rank orders in PAI for the two time intervals considered. However, it is important to note that some provenances such as Bacon Point 

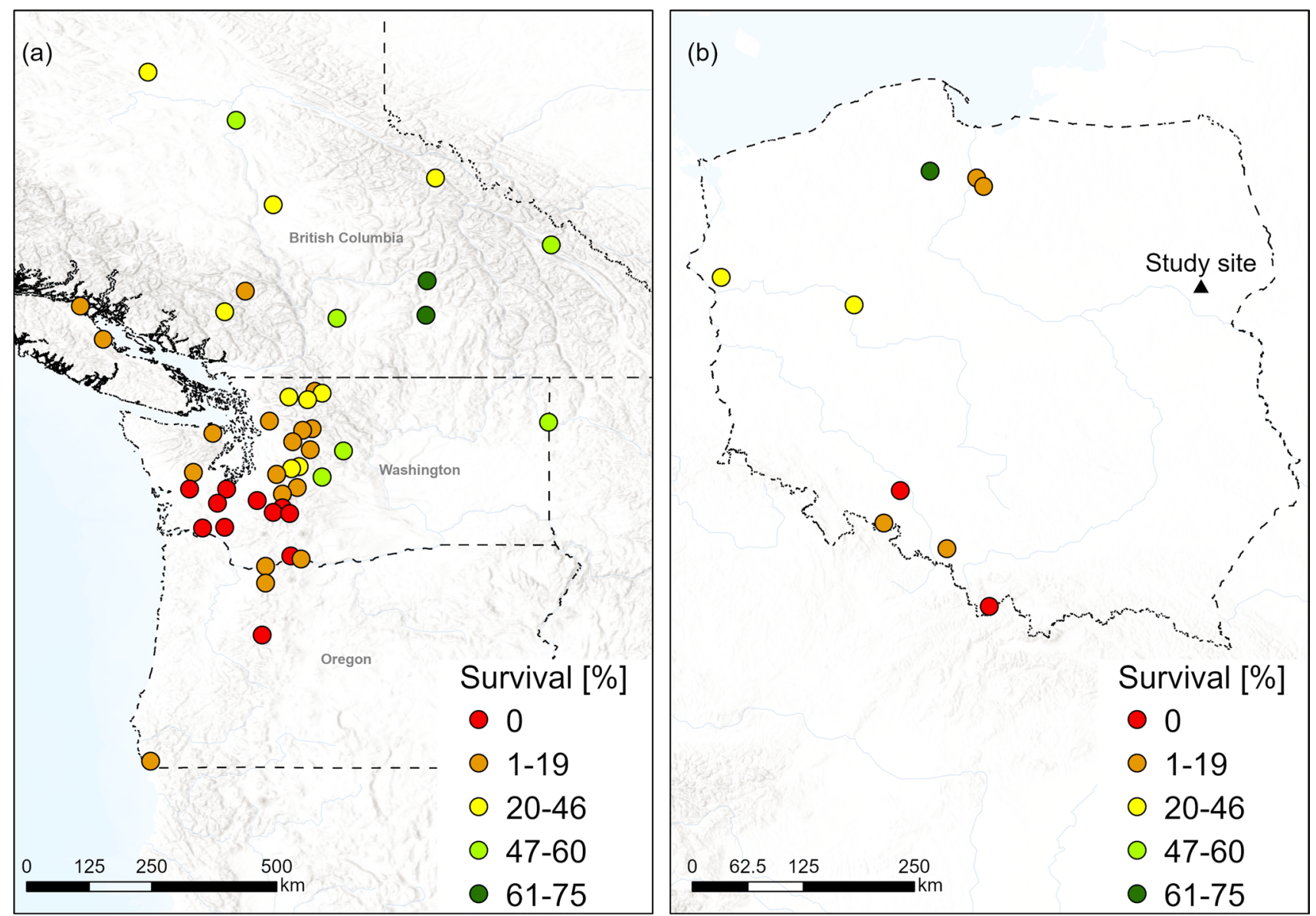

Fig. 3 Diversity of the survival rate in the tested populations from a the US and Canada and $\mathbf{b}$ the local landrace populations in Poland

[17-c-N-WA], Chester Morse Lake [26-c-N- WA] and Chiwaukum [24-c-N- WA] changed their rank order due to an increase in productivity during the second time interval (an increase of 9, 11 and 7 positions, respectively, in the $\mathrm{PAI}_{36-48}$ ranking compared to the ranking for $\mathrm{PAI}_{0-36}$ ) relative to other provenances (Table 3 ).

A cluster analysis based on the volume of individual trees and survival rate at age 48 revealed five distinct performance classes (Fig. 6). Trees in cluster 1, consisted of the best performing provenances, White Lake [7-i-S-BC], Salmon Arm [6-i-S-BC] and Wirty [47-i-N- PL], which were characterized by both the highest volume and survival rate, while trees in cluster 2 exhibited above average volume and survival. Cluster 3 gathered the worst performing provenances that did not survive to age 48 . Provenances in cluster 4 had low survival (5.5-18.4\%) and average volume, while provenances in cluster 5 had below average survival (24.3-45.5\%) and above average productivity (Fig. 6). The geographical distribution of the populations belonging to individual clusters are shown in Fig. 7.

\section{Geographical trends}

All geographic characteristics, i.e. latitude, longitude and elevation of seed sources, significantly impacted the growth and survival rate of provenances at the Rudka study site. The highest portion of variation (Table 4) was explained by survival rate $(>80 \%)$ and stand volume $(>77 \%)$. As the $\mathrm{V}_{\text {ha }}$ was calculated on the basis of both productivity-related traits (DBH and $\mathrm{H}$ ) and survival rate, we further present the results of the GAM analysis for $\mathrm{V}_{\mathrm{ha}}$ at age 48 years only.

The partial effects of the geographic variables on stand volume were estimated from the spline functions presented in Fig. 8. The fitted smooth function showed a significant effect when confidence intervals (CI) did not include zero. More northern origin seed sources positively affected stand volume, and the largest positive effect on the dependent variable, i.e. an increase of approximately $59 \mathrm{~m}^{3} \mathrm{ha}^{-1}$ per $1^{\circ}$ of latitude, was observed in the latitude range between $47-54^{\circ} \mathrm{N}$ (Fig. 8a). In general, provenances from the range of $50-54^{\circ} \mathrm{N}$ had significantly higher stand volumes than seed sources from the range of $42-48^{\circ} \mathrm{N}$. In terms of the effect of longitude on stand productivity, the best performing 


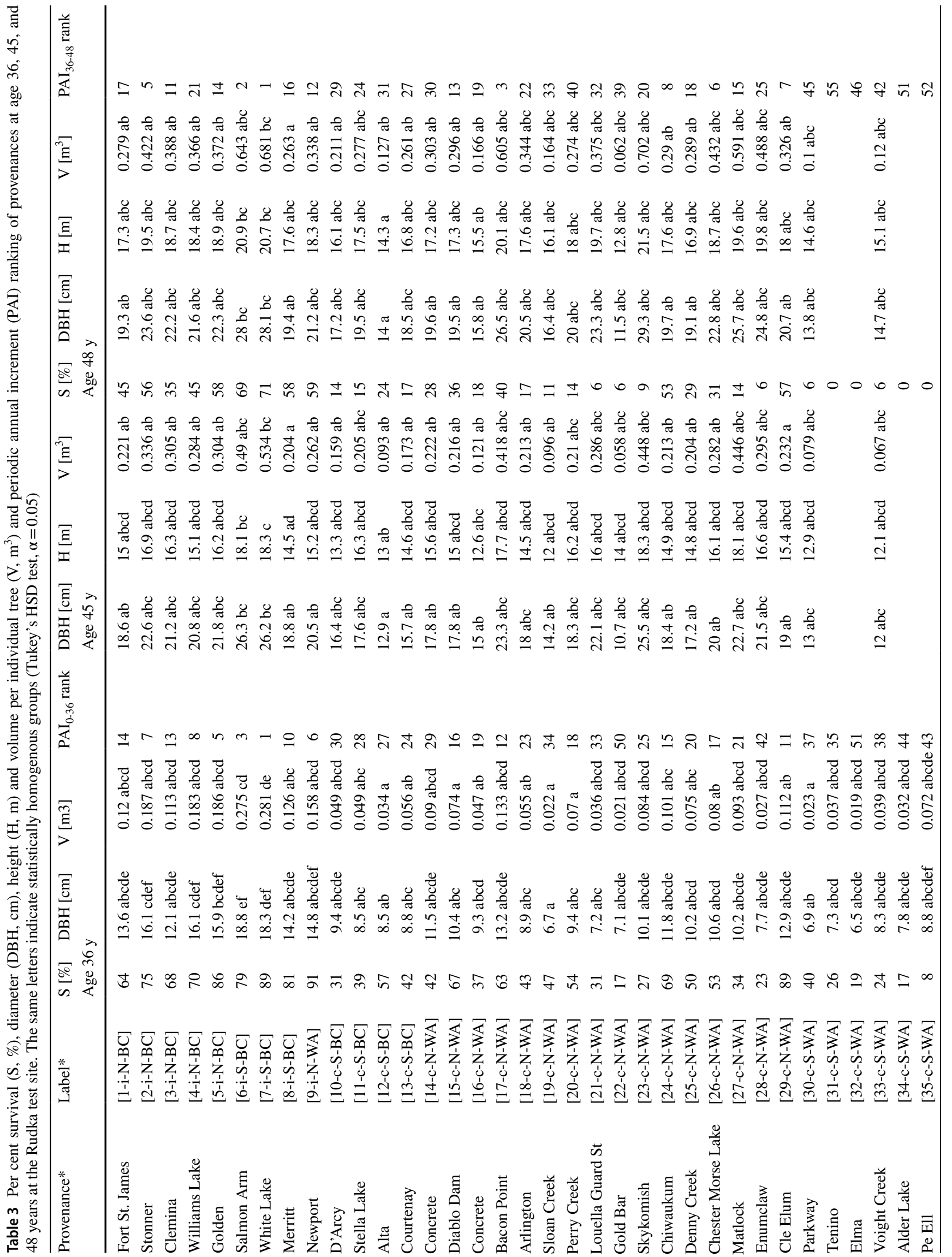




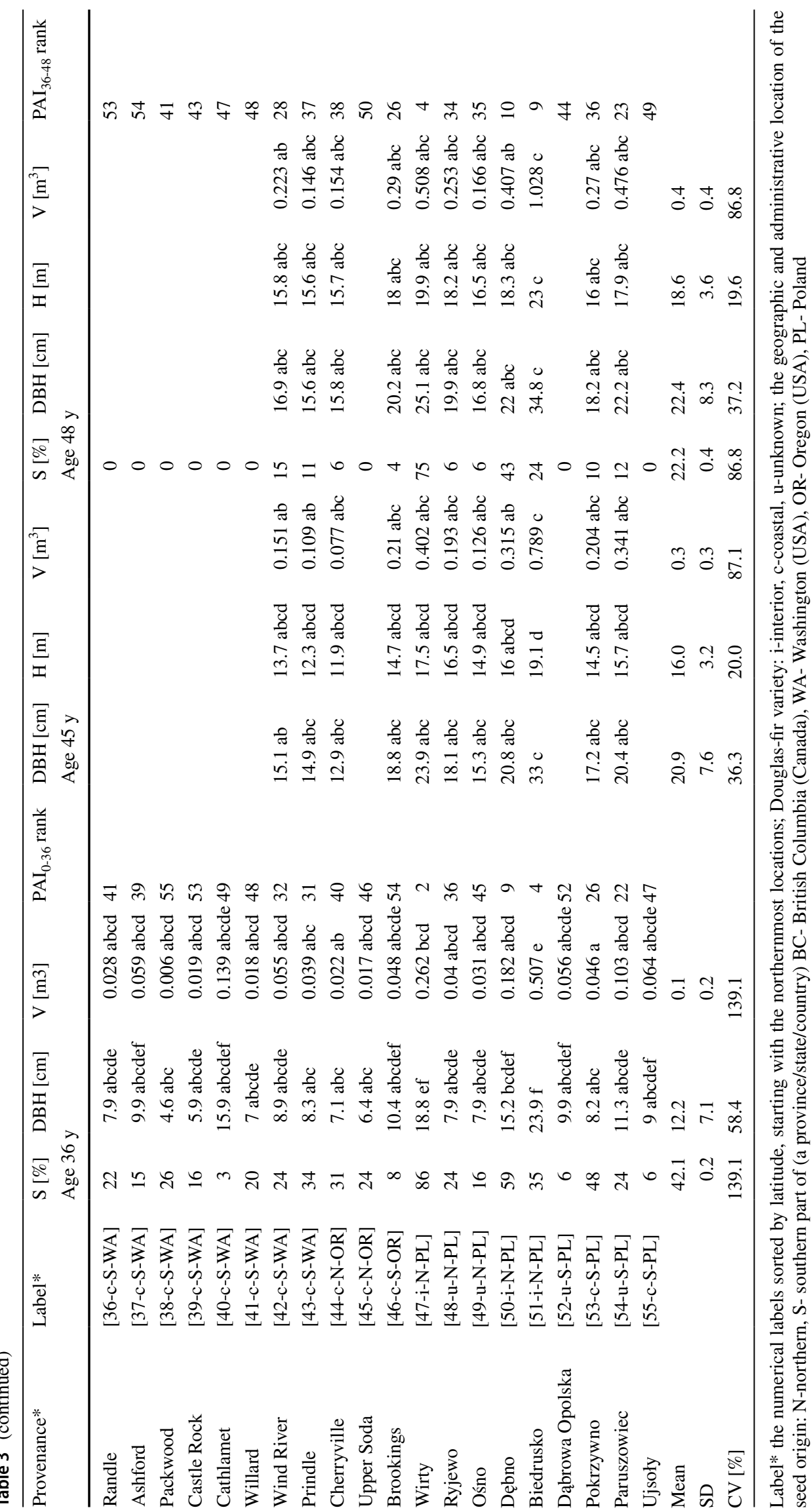




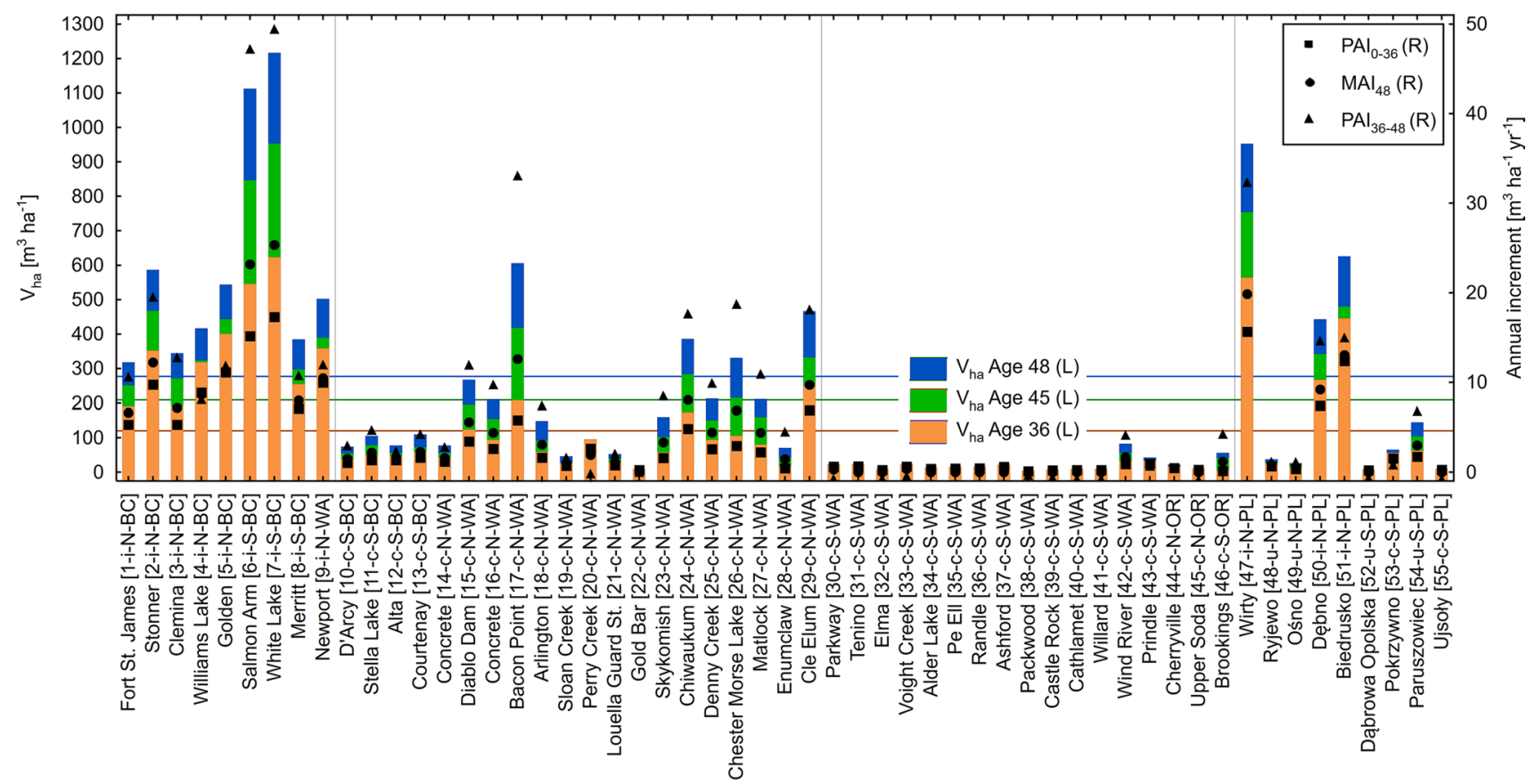

Fig. 4 Stand volume on an area basis for individual Douglas-fir provenances at the Rudka test site, taking into account the survival rate. Provenances without symbols beyond age 36 were no longer repre-

provenances were from continental origins $\left(117-120^{\circ} \mathrm{W}\right)$. The western locations, from the Pacific Coast Range, negatively affected stand volumes at Rudka (Fig. 8b). The sharpest decreasing trend for the dependent variable was found for longitudes between $119-121^{\circ} \mathrm{W}$. In this range, the estimated stand volume decreased by $213 \mathrm{~m}^{3} \mathrm{ha}^{-1}$ per $1^{\circ}$ of longitude, along the gradient from the continental/interior longitudes (with the highest volumes) to the Pacific Coast locations $\left(121-126^{\circ} \mathrm{W}\right)$. The elevation of seed sources positively affected stand volume for the origins up to $\sim 700 \mathrm{~m}$ a.s.l., with the optimum at around $500(400-650) \mathrm{m}$ a.s.1.. Further increases in altitude in the range of $675-900 \mathrm{~m}$ a.s.l. resulted in a slight negative trend in which estimated volume decreased by $190 \mathrm{~m}^{3} \mathrm{ha}^{-1}$ (Fig. 8c).

\section{Climatic trends}

We found that the greatest variation in productivity-related traits was explained using five bioclimatic variables: annual mean temperature (MAT), temperature annual range (continentality), mean annual precipitation sum (MAP), isothermality, which quantifies the day-to-night temperature oscillations relative to the summer-to-winter (annual) oscillations, and precipitation seasonality (PS coef. of variance). These variables jointly explained, in various years of measurement, from 54.6 to $62.2 \%$ of the variance in $\mathrm{DBH}$, approximately $57 \%$ of the variance in $\mathrm{H}$, and $65 \%$ of the variance in $\mathrm{V}_{\mathrm{ha}}$, and from 65.9 to $70.7 \%$ in survival (Table 5). As the $\mathrm{V}_{\text {ha }}$ was sented at the trial. Horizontal lines denote the average stand volume at a particular age

calculated on the basis of both productivity-related traits (DBH and $\mathrm{H}$ ) and survival, we further present the results of the GAM analysis for the $\mathrm{V}_{\text {ha }}$ at age 48 years only (Fig. 9).

The partial effects of the investigated climatic variables on productivity at age 48 expressed by $\mathrm{V}_{\mathrm{ha}}$ are presented in Fig. 9. The largest partial effect among selected climatic variables was observed for precipitation seasonality. The increase in the index of the precipitation seasonality from 25 to 45 resulted in a rapid decrease in productivity (Fig. 9d). However, from the value of the index of 50, a further increase in precipitation seasonality did not result in changes in productivity. The partial effect of this variable on productivity was positively associated with seed sources originating from sites with less variation in precipitation during the year than at Rudka. The partial effect of the mean annual precipitation (MAP) was relatively weak in the entire range of precipitation values, however, increasing values of this variable showed a positive effect on productivity (Fig. 9c). Similarly, a positive effect was observed in the case of the continentality index and mean annual temperature (MAT) variables. In both cases, the confidence intervals included a zero value over the entire range of $\mathrm{X}$-axis values, although the increase in continentality index of the population origin from 22 to 36 resulted in an increase in productivity of approximately $300 \mathrm{~m}^{3}$ (Fig. 9a). A similar increase in productivity was observed when MAT of the origin increased from 5 to $9{ }^{\circ} \mathrm{C}$ with no further positive effect for higher MAT values (Fig. 9b). 

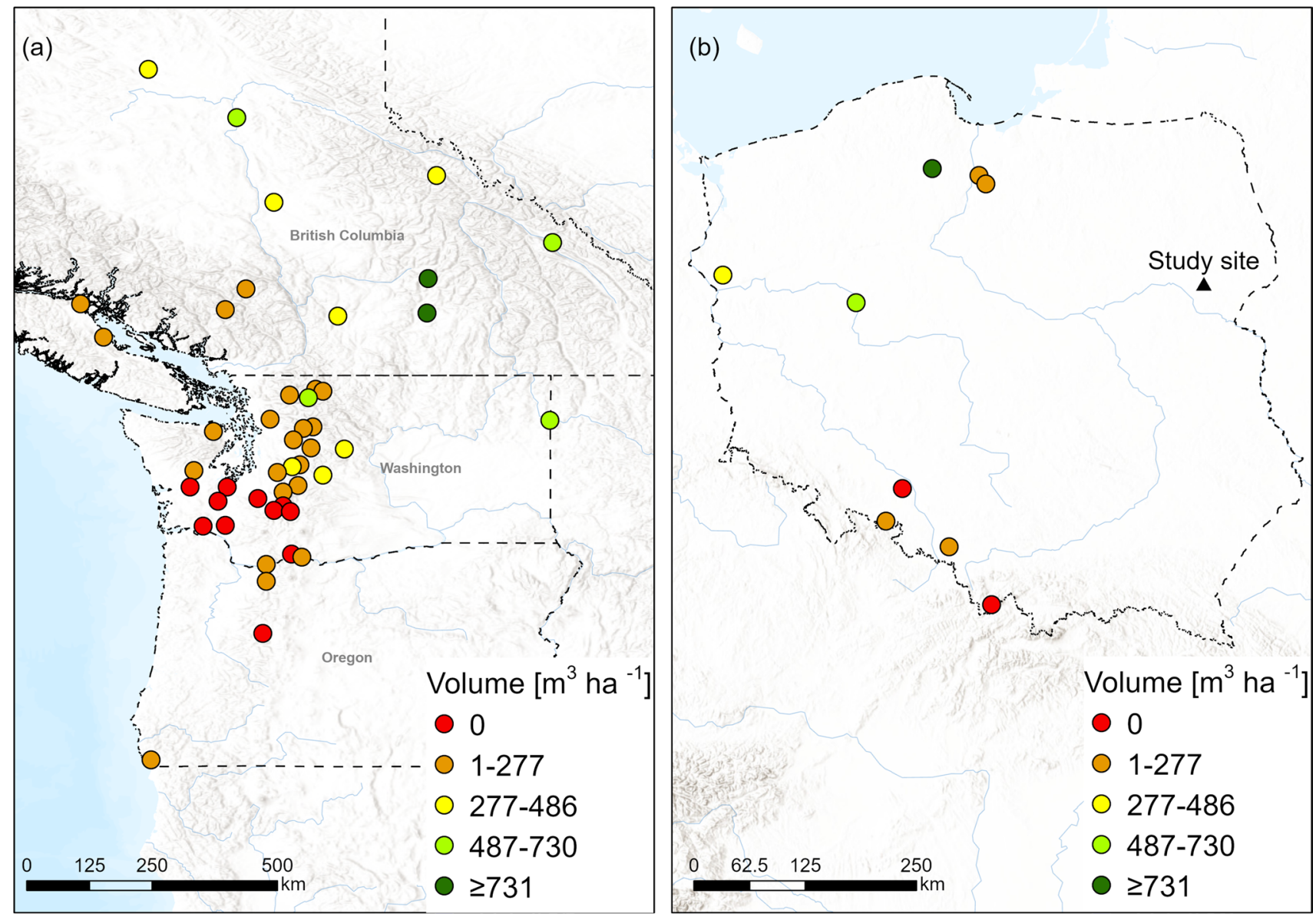

Fig. 5 Diversity in stand volume $\left(\mathrm{m}^{3} / \mathrm{ha}\right)$ at age 48 in the tested populations from a the United States and Canada and $\mathbf{b}$ Poland

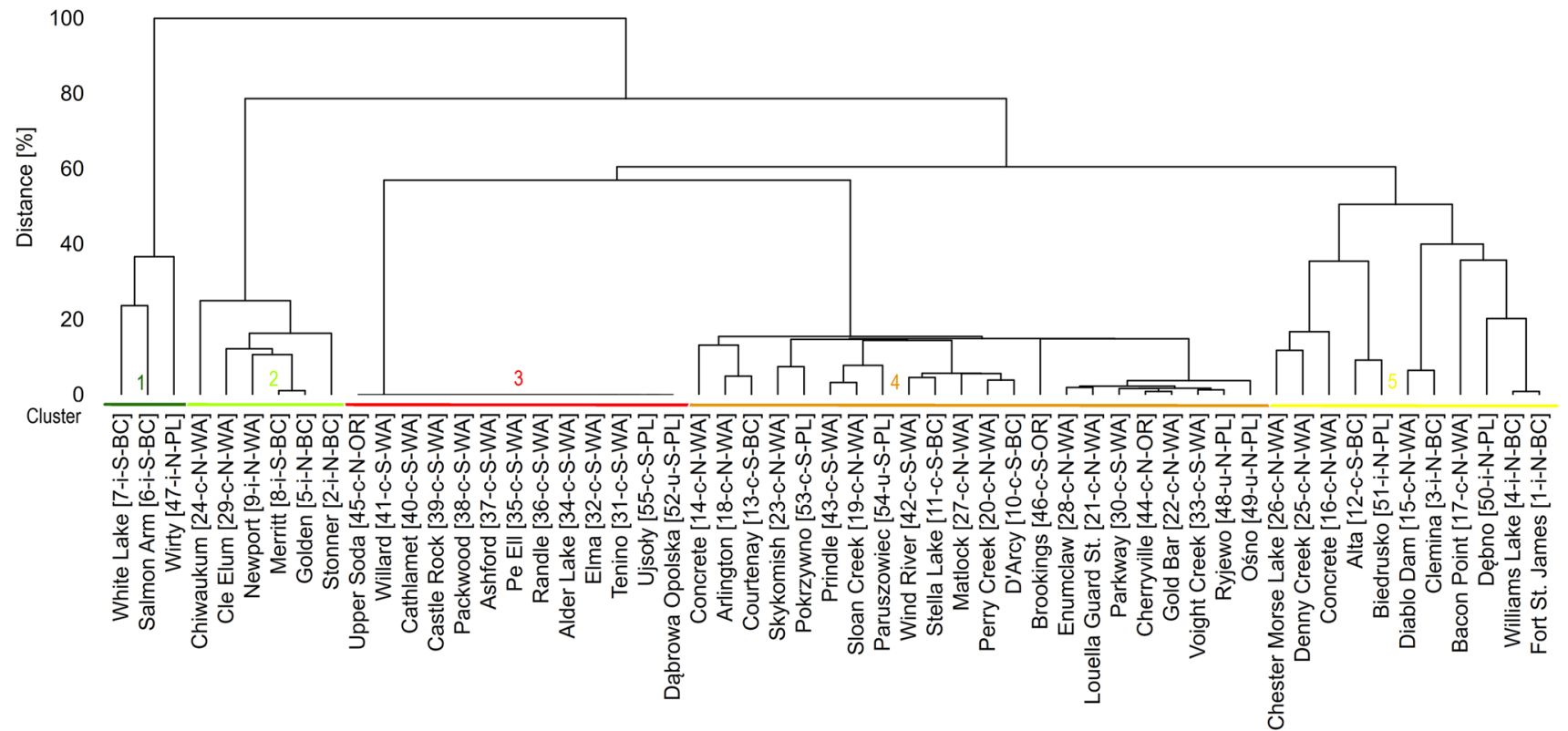

Fig. 6 Clustering of 55 provenances of Douglas-fir based on volume of individual trees and survival rate at age 48 at the test site in Rudka, Poland 

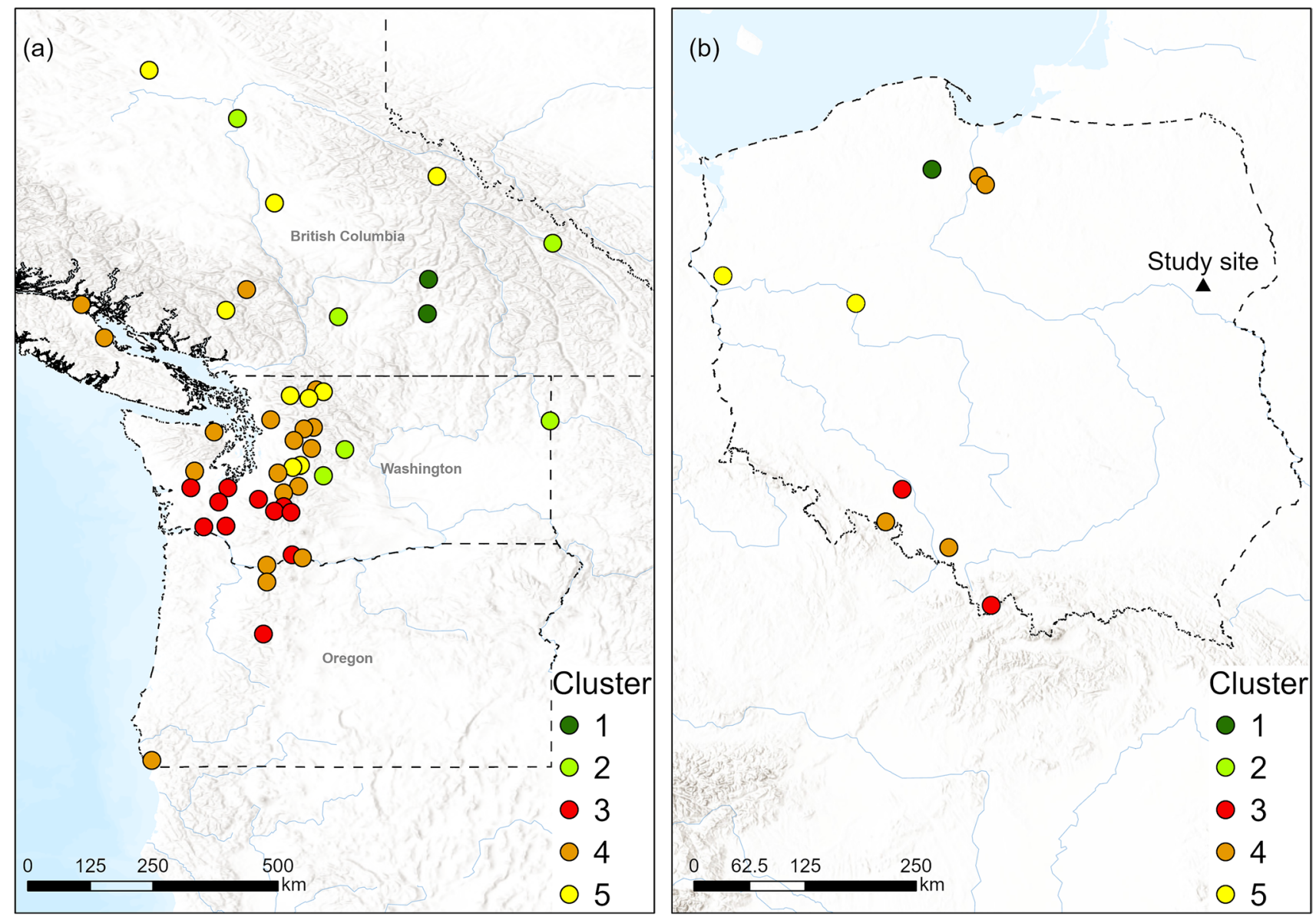

Fig. 7 Spatial distribution of provenances grouped in clusters based on volume of individual trees and survival rate at age 48

Table 4 The results of the GAM analysis (adjusted coefficient of determination $\mathrm{R}_{\text {adj }}^{2}$ ) based on all geographical characteristics for diameter at breast height $(\mathrm{DBH}, \mathrm{cm})$, height $(\mathrm{H}, \mathrm{m})$, volume per hectare $\left(\mathrm{V}_{\mathrm{ha}}, \mathrm{m}^{3} \mathrm{ha}^{-1}\right)$ and survival $(\mathrm{S}, \%)$

\begin{tabular}{llcll}
\hline Age [years] & $\mathrm{DBH}[\mathrm{cm}]$ & $\mathrm{H}[\mathrm{m}]$ & $\mathrm{V}_{\mathrm{ha}}\left[\mathrm{m}^{3} \mathrm{ha}^{-1}\right]$ & $\mathrm{S}[\%]$ \\
\hline 36 & 64.3 & - & 81.1 & 86.3 \\
45 & 64.7 & 62.7 & 78.3 & 80.3 \\
48 & 61.4 & 62.0 & 77.4 & 80.3 \\
\hline
\end{tabular}

The effect of isothermality showed a variable effect on productivity. The highest productivity was associated with the isothermality index from approximately 30-37\% (Fig. 9e). The decrease or increase in isothermality beyond this range resulted in a decrease in productivity.

\section{Discussion}

Our study showed considerable variation in survival and productivity-related traits among examined Df seed sources in the continental climatic conditions of eastern Poland.
These results emphasize the importance of selecting appropriate provenances for use at particular locations to ensure the optimum survival, productivity and resilience of planted forests in the long-term. The analysis relating geographic location and climatic variables at the area of origin of Df populations with the responses in growth parameters at the Rudka test site in eastern Poland sheds light on the capacity for within-species adaptation and can facilitate the interpretation of results for species introductions and limitations of seed source selections.

Df provenances from interior $\mathrm{BC}$, WA and the progeny of the landrace stand in Wirty [47-i-N-PL], showed the best performance to conditions at the Rudka study site located in the continental climate of eastern Poland. In contrast, most provenances from the coastal Df range exhibited maladaptation to climatic conditions at the test site, which was reflected by the high mortality of trees and/or their low productivity. Our findings are in clear contrast to most European studies, where Df populations originating from coastal $\mathrm{BC}$, the west side of the Cascade Range and coastal regions of WA and OR are recommended for Europe (Kleinschmit and Bastien 1992; Isaac-Renton et al. 2014; Chakraborty 

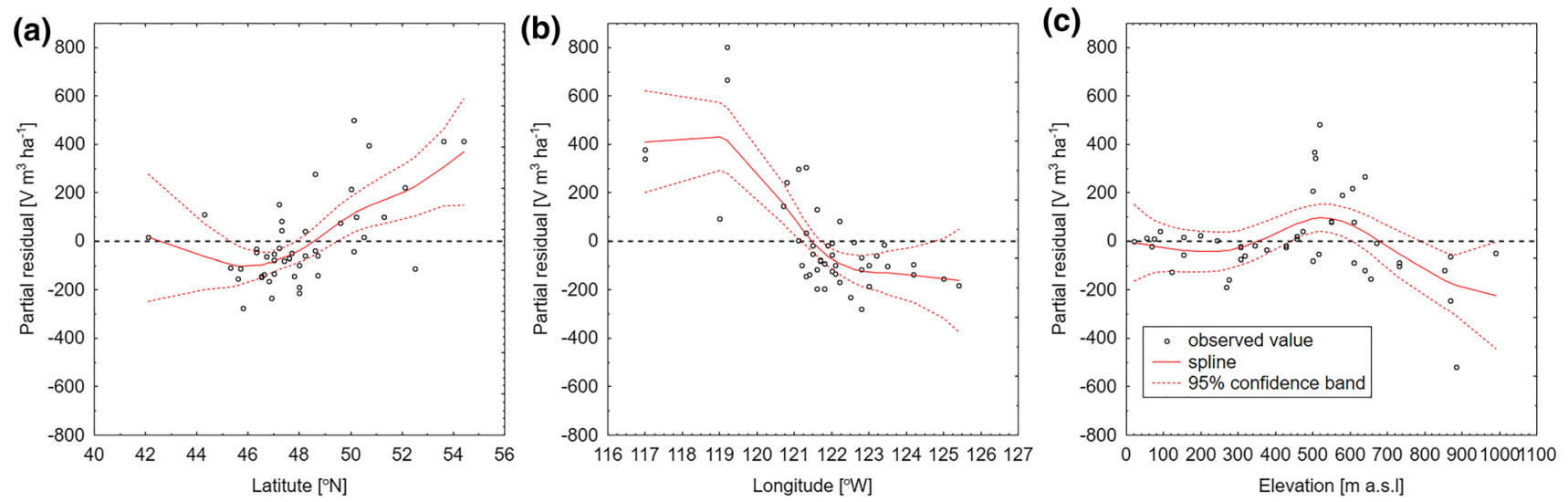

Fig. 8 Spline-curves showing the partial effects of a latitude, $\mathbf{b}$ longitude, and $\mathbf{c}$ elevation on a volume per ha basis in Douglas-fir at age 48 years $\left(\mathrm{R}^{2}=77.4 \%\right)$ at the Rudka test site

Table 5 Adjusted coefficients of determination $\left(\mathrm{R}^{2}{ }_{\text {adj }}\right)$ in the GAM analysis based on five bioclimatic variables: annual mean temperature (MAT), isothermality, temperature annual range (continentality), mean annual precipitation (MAP) and precipitation seasonality (PS coef. of variance) explaining jointly the largest amount of variation (among 19 bioclimatic variables tested) in diameter at breast height $(\mathrm{DBH}, \mathrm{cm})$, height $(\mathrm{H}, \mathrm{m})$, volume per hectare $\left(\mathrm{V}_{\mathrm{ha}}, \mathrm{m}^{3} \mathrm{ha}^{-1}\right)$ and survival (S, \%) for three ages at the Rudka test site

\begin{tabular}{llcll}
\hline Age [years] & $\mathrm{DBH}[\mathrm{cm}]$ & $\mathrm{H}[\mathrm{m}]$ & $\mathrm{V}_{\mathrm{ha}}\left[\mathrm{m}^{3} \mathrm{ha}^{-1}\right]$ & $\mathrm{S}[\%]$ \\
\hline 36 & 62.2 & - & 66.2 & 65.9 \\
45 & 56.6 & 57.7 & 65.2 & 70.7 \\
48 & 54.6 & 56.9 & 64.2 & 70.7 \\
\hline
\end{tabular}

et al. 2015, 2016). In these studies, projecting the potential provenance performance (expressed as either dominant height or basal area), in relation to climate at the origin and planting sites, some interior Df sources were also identified as optimal, but with limited supporting evidence for such recommendations (Chakraborty et al. 2016). Moreover, the set of independent data on which the model was evaluated lacked the low-elevation sites with a continental climate (Chakraborty et al. 2016), making our observations particularly important in the context of selection decisions and recommendations regarding optimal Df sources for lowland sites with continental climates.

A group of 10 populations originating from south-eastern WA, one from OR, and two landrace populations (Dąbrowa Opolska [52-u-S-PL] and Ujsoły [55-c-S-PL]) had 100\% mortality by age 48 at the test site. The research carried out in winter 1978/79 at Rudka indicated that frost susceptibility was the major contributor to sapling mortality at the early stage of this experiment (Burzyński 1990). These observations correspond well with the geographical patterns of Df frost resistance revealed in other IUFRO test sites, where interior populations, especially from $\mathrm{BC}$, were the most resistant to early and winter frosts (Braun and Wolf 2001).

Previous research has shown that a trade-off exists between frost tolerance and growth performance in Df populations. The interior variety typically shows higher frost resistance but lower growth potential when compared to the coastal variety (Rehfeldt 1977; St Clair et al. 2005; Krakowski and Stoehr 2009; Benowicz et al. 2020). However, in our current research, where the most continental conditions among the IUFRO Df test sites in lowland Europe exist, we found that the interior populations showed not only superior frost-resistance, but also superior productivity in a continental climate. Thus, our results provide evidence to support the earlier suggestions by Isaac-Renton et al. (2014), that for the continental climates in Europe, the interior Df provenances are likely to be a more appropriate and a safer choice for reforestation than coastal provenances.

Productivity of Df is one of its greatest advantages (Chylarecki 2004; Krakowski and Stoehr 2009), which has driven worldwide interest in this species. The best performing provenance at our Rudka test site was from White Lake [7-i-S$\mathrm{BC}]$, achieving a stand volume of $1216 \mathrm{~m}^{3} \mathrm{ha}^{-1}$, with a mean annual increment (MAI) of $25 \mathrm{~m}^{3} \mathrm{ha}^{-1} \mathrm{yr}^{-1}$ at age 48. This MAI is higher than the values reported from stands within the natural range of Df in the USA (Acker et al. 1998) and Canada (Isaac-Renton et al. 2020), and at other European sites (Bastien et al. 2013). Df in our experiment exceeded the productivity of almost all native tree species at a similar age occurring in Poland (Jaworski 2004). Contrary to the results obtained in earlier studies, the current work has shown the high productivity potential of Df in the most eastern/continental research location tested in Europe and confirms the potential usefulness of this species for forestry outside the currently recommended planting zones in Poland and Europe (Chylarecki 2004). 
Fig. 9 Spline-curves showing the partial effects of a continentality, $\mathbf{b}$ annual mean temperature, $\mathbf{c}$ annual precipitation, $\mathbf{d}$ precipitation seasonality, and e isothermality on a volume per ha basis at age 48 years $\left(\mathrm{R}^{2}=64.2 \%\right)$. The vertical doted lines denote climatic conditions at the Rudka test site in eastern Poland
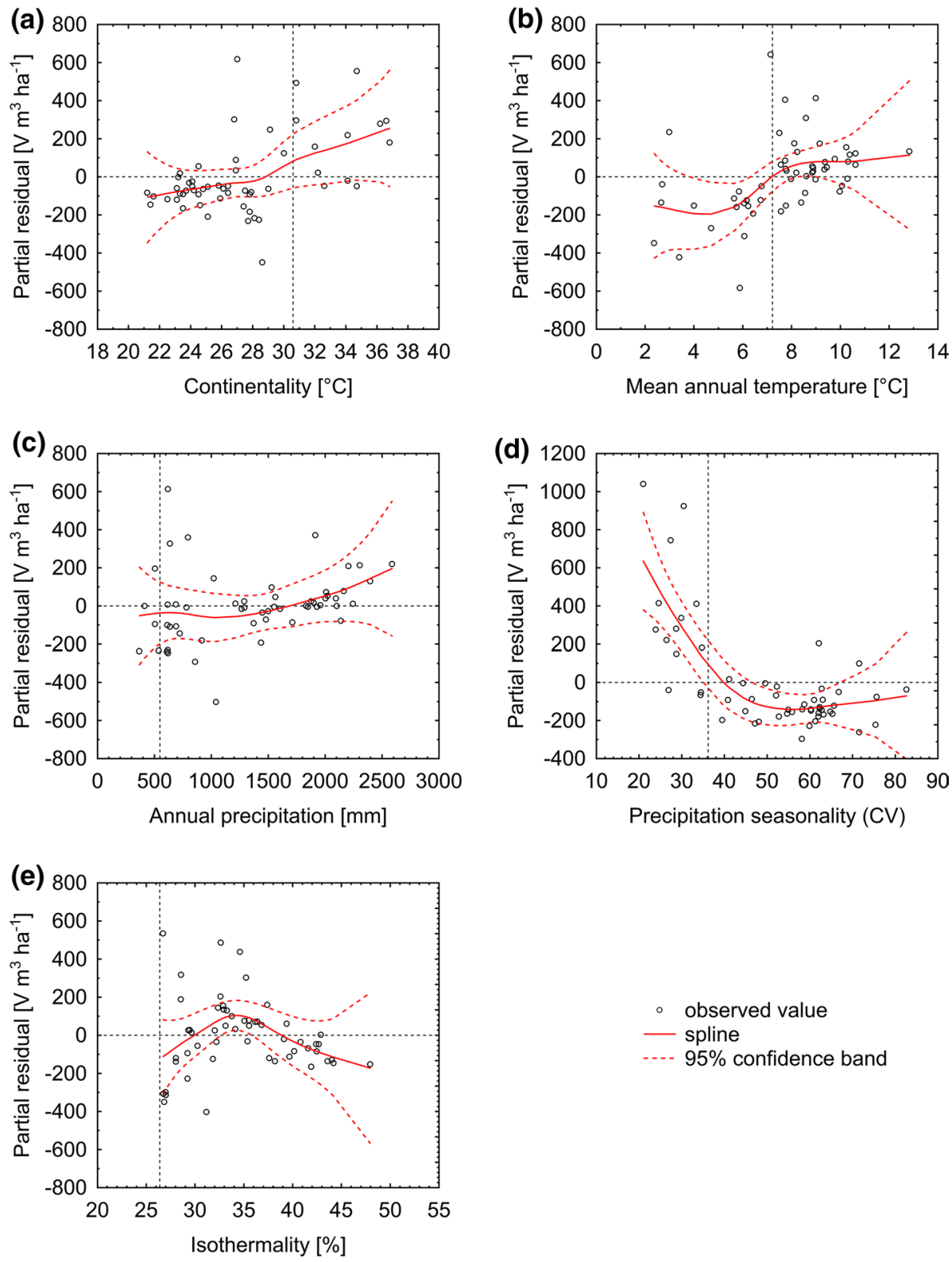

- observed value

- spline

-.. 95\% confidence band
The analysis of growth dynamics in our study revealed that the best performing provenances, i.e. White Lake [7-i-SBC] and Salmon Arm [6-i-S-BC], maintained their dominant position throughout the experimental period, i.e. in the two time intervals considered. Due to their better adaptability to environmental conditions in the initial phase of tree growth (frost- resistance), they were characterized not only by a higher survival rate but also their annual increment was faster than that of the trees from the other provenances. Over time, with canopy closure in the experimental area, the trees of these two provenances were able to effectively compete for light, water, and nutrients as they developed larger stems and crowns faster than the trees from other provenances. It seems possible that their exceptionally high PAI in the second time interval (2005-2017) resulted from a favourable combination of their adaptability, plasticity, and the maintenance of their dominant position in the canopy, while trees from some other provenances were gradually overtopped and suppressed. Weaker competitiveness and plasticity of trees seems to have played a role in tree mortality, especially in the second time interval of our study. However, this issue is beyond the scope of the present study and no conclusions should be drawn on this aspect without additional analyses ( e.g. dendrochronological study).

The analysis of geographic trends in growth parameters and survival rates at Rudka showed clear relationships with latitude, longitude and elevation of the seedlot provenances. These relationships explained over $80 \%$ of the variation in survival and over $77 \%$ of the variation in volume per hectare. According to the GAM analysis, 
the optimum range of geographic ranges from which Df provenances are recommended for introduction into continental climates in the lowland region of Central Europe is from $50-54^{\circ} \mathrm{N}$ latitude and $<119^{\circ} \mathrm{W}$ longitude, with an elevation not higher than $700 \mathrm{~m}$ a.s.1.. The longitudinal variation corresponds more to the distance from the ocean, associated with continentality in North America, than to absolute degrees of longitude (Campbell and Sorensen 1978; Rehfeldt et al. 2014). The trend in productivity related to seed source altitude was rather weak in our study compared to the typically steep clines shown previously in Df (Rehfeldt 1989; Rehfeldt et al. 2014). However, the provenances included in our experiment did not represent the whole altitudinal range of the species distribution.

Among the five bioclimatic characteristics of seed origin that explained the largest part of the variation in productivity-related traits in our study, the precipitation seasonality had the highest impact, whereas the MAP, MAT, continentality and isothermality had smaller effects. Similar to our results, the MAP of the origin sites was not a significant factor in models predicting growth performance of Df in Austria and Germany, where even at the driest sites, the coastal Df variety performed well (Chakraborty et al. 2015). However, moisture conditions seem to be important as the summer heat:moisture index was among the most influential factors affecting the projected provenance performance in Chakraborty's et al. studies (Chakraborty et al. 2015, 2016) and, as mentioned, precipitation seasonality was the most important bioclimatic factor in our study. At the Rudka site, years with an annual precipitation higher than $600 \mathrm{~mm}$ are rare, and precipitation occurs throughout the year although the largest portion of rainfall occurs during the summer (Fig. 1). In contrast, most of the provenances tested in Rudka originated from the west (coastal) side of the Cascade Mountains in WA (optimal conditions for the Df in its natural range), where the annual precipitation is $1800-2200 \mathrm{~mm}$, with the majority of this precipitation occurring during the winter months (Chylarecki 2004). Thus, with the abundance of precipitation and relatively small temperature amplitudes during the year, the oceanic climate of the western Cordillera is difficult to compare with the climate of eastern Poland, which is moderately cold with prevailing continental conditions (Kondracki 2009). The inferior growth potential of the coastal variety in our study can therefore be explained by an incompatibility in climatic conditions between origin and test site. From the range of climatic variability covered by Df provenances sampled in our study, the climate in BC is most similar to that of eastern Poland. In particular, the continental plateau between the Coastal Range and the Rocky Mountains, where the interior Df provenances from Salmon Arm [6-i-S-BC] and White Lake [7-i-S-BC] originate, and where the climatic conditions are comparable to our study site, these two provenances performed best at Rudka.

Although our study was not specifically designed to investigate physiological responses to water stress, our findings suggest that even a small amount of precipitation, occurring uniformly during the year (small CV of precipitation seasonality), can provide sufficient resources to support good performance of Df at more continental locations. When taking into account global and regional projections for the direction of climate change and the speed of change as well as the magnitude and frequency of extreme events including droughts and heat events (IPCC, 2013), Df populations from regions with relatively cool winters and arid summers may be most adapted to cope with drought conditions that are expected in the future (Bansal et al. 2015). In light of these findings, it appears that the interior Df variety, which showed better performance at the Rudka site, will be a safer and more profitable choice for eastern Poland under future climate projections. In the context of the recommendations regarding reforestation under projected climate change, it is possible that other Df provenances might grow as well as the interior variety or even better in a new, future climate at the site. However, the results of our study indicate that frost resistance is, and likely will remain, an important factor affecting early survival and success of Df plantations grown in continental climates, which is critical for plantation success. Future climates are projected to be warmer (Collins et al. 2013), but those projections do not preclude the occurrence of extreme weather phenomena, especially the late and early frosts in locations with continental-type climates, and the populations from the interior Df range with superior growth would be desirable for such sites (Chakraborty et al. 2019).

The local landraces which were tested in our study were clearly distinguishable between the interior and coastal types based on survival and biometric characteristics ( $\mathrm{H}$ and $\mathrm{DBH})$. The landraces of the interior type, located at Wirty [47-i-N-PL], Biedrusko [51-i-N-PL] and Dębno [50-i-N$\mathrm{PL}]$, had significantly higher productivity at Rudka than those orginating from the coastal native range. The latter suffered from frost damage at the early stage of the experiment (Burzyński 1990), which resulted in high mortality rates and inferior growth capacity. Yet, not all the landraces of the interior type had satisfactory survival, and the Wirty landrace was clearly superior for both growth and survival. Certainly, stands that were planted with originally introduced seed sources underwent acclimation to the sites, and the non-adapted individuals which died-off did not produce offspring. However, those stands were not previously progeny-tested, thus their value as landrace populations is not known. Our study contributes to closing this knowledge gap. However, as we have no information on the origin of the landrace populations, we also have no knowledge about the 
level of genetic variation they represent without additional genomic testing. It may be the case that progeny of some of those stands show poorer adaptive capacity because of the limited genetic variation potentially due to a founder effect. Further studies would need to be conducted to determine the level of genetic variation in the landrace stands and their progeny. Our study showed that the interior Df variety could be successfully planted in eastern Poland, however, performance of this variety was not uniform and any new introductions would need to be fully tested. It should be noted, however, that our results are based on a single test site, and we should be cautious with findings from this study when making reforestation recommendations at a broader scale. More field tests are needed, especially in continental-type climates, to confirm the suitability of interior Df provenances and local landrace populations for consideration in forestry practice. Our findings indicate that the seed base for Df in Poland should be continuously improved and perhaps even enriched with new genetic material from the natural range of this species, taking geographic and climatic criteria into account. Further support should be considered with additional field trials, early greenhouse screening and DNA testing.

\section{Conclusions}

Overall, our results show a significant impact of geographic location and climatic conditions of the seed source origin of Df on survival and growth rate in a continental test site in eastern Poland. It appears that both geographic and climate characteristics should not be treated independently, as geographic location integrates many factors shaping local adaptation, including climate characteristics, phenology, photoperiod length, and angle of solar radiation, all of which affect plant growth. The interior Df variety performed best at our study site, which is in clear contrast to many sites with temperate climates in Europe, where the coastal variety is recommended. Thus, under projected climate change, our study revealed the potential for additional introductions (assisted migration) of Df, especially the interior variety, beyond the current recommended planting zones in Europe. The tested Df provenances did not show sensitivity in their response related to annual precipitation or mean annual temperature, however, they did show sensitivity to precipitation seasonality which implies that seasonal droughts could potentially limit the growth capacity of Df at such sites. Furthermore, the significant effect of late frosts on survival of some provenances, at an early age, indicates that these provenances should be avoided in locations with more continental climates in Europe. Therefore, we suggest that assisted migration programs should consider the limitations imposed by both late frost events and projected increases in frequency of drought events in guiding future selections. The landraces tested in this single study site showed mixed results as potential seed sources. Our study shows that local landraces in Poland could be enriched with new genetic material from the natural interior Df range of this species, with particular attention being taken as to the geographic location and climate, relative to the deployment area under consideration in more continental climates. Testing of an enriched source population would also benefit forest practitioners in determining site suitability in the future across both Poland and other regions in Europe.

Author Contribution Conceptualization: Marzena Niemczyk; Formal analysis: Marzena Niemczyk, Jarosław Socha and Piotr Mroczek; Funding acquisition: Marzena Niemczyk; Investigation: Tomasz Wojda and Marzena Niemczyk; Methodology: Marzena Niemczyk; Writing original draft preparation: Marzena Niemczyk and Daniel J. Chmura; Writing - review and editing: all authors.

Funding This manuscript was developed under a Grant No. 260227 to Marzena Niemczyk within a Scholarship Fund of the Forest Research Institute.

Data availability The datasets generated and/or analysed during the current study can be available on request.

\section{Declarations}

Conflicts of interest The authors declare that they have no conflict of interest.

Open Access This article is licensed under a Creative Commons Attribution 4.0 International License, which permits use, sharing, adaptation, distribution and reproduction in any medium or format, as long as you give appropriate credit to the original author(s) and the source, provide a link to the Creative Commons licence, and indicate if changes were made. The images or other third party material in this article are included in the article's Creative Commons licence, unless indicated otherwise in a credit line to the material. If material is not included in the article's Creative Commons licence and your intended use is not permitted by statutory regulation or exceeds the permitted use, you will need to obtain permission directly from the copyright holder. To view a copy of this licence, visit http://creativecommons.org/licenses/by/4.0/.

\section{References}

Acker SA, Sabin TE, Ganio LM, McKee WA (1998) Development of old-growth structure and timber volume growth trends in maturing Douglas-fir stands. For Ecol Manage 104:265-280. https://doi. org/10.1016/S0378-1127(97)00249-1

Aertsen W, Kint V, van Orshoven J et al (2010) Comparison and ranking of different modelling techniques for prediction of site index in Mediterranean mountain forests. Ecol Modell 221:1119-1130. https://doi.org/10.1016/j.ecolmodel.2010.01.007

Aitken SN, Whitlock MC (2013) Assisted gene flow to facilitate local adaptation to climate change. Annu Rev Ecol Evol Syst 44:367388. https://doi.org/10.1146/annurev-ecolsys-110512-135747 
Aitken SN, Yeaman S, Holliday JA et al (2008) Adaptation, migration or extirpation: climate change outcomes for tree populations. Evol Appl 1:95-111. https://doi.org/10.1111/j.1752-4571.2007. 00013.x

Allen CD, Macalady AK, Chenchouni H et al (2010) A global overview of drought and heat-induced tree mortality reveals emerging climate change risks for forests. For Ecol Manage 259:660-684. https://doi.org/10.1016/j.foreco.2009.09.001

Andalo C, Beaulieu J, Bousquet J (2005) The impact of climate change on growth of local white spruce populations in Quebec, Canada. For Ecol Manage 205:169-182

Austin MP (2002) Spatial prediction of species distribution: an interface between ecological theory and statistical modelling. Ecol Modell 157:101-118. https://doi.org/10.1016/S0304-3800(02) 00205-3

Avery TE, Burkhart HE (2015) Forest measurements. Waveland Press

Bansal S, Harrington CA, Gould PJ, St.Clair JB, (2015) Climate-related genetic variation in drought-resistance of Douglas-fir (Pseudotsuga menziesii). Glob Chang Biol 21:947-958. https://doi.org/ $10.1111 / \mathrm{gcb} .12719$

Barzdajn W (2013) Porównanie rodów daglezji ( Pseudotsuga menziesii ( Mirb.) Franco ) w doświadczeniu w Nadleśnictwie Manowo. Sylwan 157:204-212

Bastien J-C, Sanchez L, Michaud D (2013) Douglas-Fir (Pseudotsuga menziesii (Mirb.) Franco). In: Pâques LE (ed) Forest Tree Breeding in Europe: current state-of-the-art and perspectives. Springer, Netherlands, Dordrecht, pp 325-369

Benowicz A, Stoehr M, Hamann A, Yanchuk AD (2020) Estimation of the F2 generation segregation variance and relationships among growth, frost damage, and bud break in coastal Douglas-fir (Pseudotsuga menziesii (Mirb.) Franco) wide-crosses. Ann for Sci 77:1-13. https://doi.org/10.1007/s13595-020-0925-9

Berney JLA (1972) Studies on the probable origin of some European Douglas-fir (Pseudotsuga menziesii [Mirb] Franco) plantations. MSc Thesis. University of British Columbia, 99 pp

Braun H, Wolf H (2001) Untersuchungen zum wachstum und zur frosthärte von douglasien-populationen in ostdeutschland. Beitr Für Forstwirtsch Und Landschaftsökologie 35:211-214

Burzyński G (1990) Wrażliwość jedlicy na mrozy zimowe w latach 1975-1980 na powierzchniach instytutu badawczego leśnictwa. Sylwan 134:37-49

Campbell RK, Sorensen FC (1978) Effect of test environment on expression of clines and on delimitation of seed zones in Douglas-fir. Theor Appl Genet 51:233-246. https://doi.org/10.1007/ BF00273770

Casañas F, Simó J, Casals J, Prohens J (2017) Toward an evolved concept of landrace. Front Plant Sci 8:1-7. https://doi.org/10.3389/ fpls.2017.00145

Chakraborty D, Wang T, Andre K et al (2015) Selecting populations for non-analogous climate conditions using universal response functions: The case of douglas-fir in central Europe. PLoS ONE 10:1-21. https://doi.org/10.1371/journal.pone.0136357

Chakraborty D, Wang T, Andre K et al (2016) Adapting Douglasfir forestry in Central Europe: evaluation, application, and uncertainty analysis of a genetically based model. Eur J for Res 135:919-936. https://doi.org/10.1007/s10342-016-0984-5

Chakraborty D, Matulla C, Andre K et al (2019) Survival of Douglasfir provenances in Austria: site-specific late and early frost events are more important than provenance origin. Ann for Sci. https:// doi.org/10.1007/s13595-019-0883-2

Chałupka W, Matras J, Barzdajn W, et al (2011) Program of conserving forest genetic resources and breeding of trees in Poland for the years 2011-2035

Chylarecki H (2004) Daglezja w lasach Polski. Bogucki Wydawnictwo Naukowe, Poznań 137 pp.
Davis MB, Shaw RG (2001) Range shifts and adaptive responses to quaternary climate change. Science 292:673-679. https://doi.org/ 10.1126/science.292.5517.673

Dyderski MK, Paź S, Frelich LE, Jagodziński AM (2018) How much does climate change threaten European forest tree species distributions? Glob Chang Biol 24:1150-1163. https://doi.org/10. $1111 /$ gcb. 13925

Fick SE, Hijmans RJ (2017) WorldClim 2: new 1-km spatial resolution climate surfaces for global land areas. Int J Climatol 37:43024315. https://doi.org/10.1002/joc.5086

Frescino TS, Edwards TC, Moisen GG (2001) Modeling spatially explicit forest structural attributes using generalized additive models. J Veg Sci 12:15-26. https://doi.org/10.1111/j.1654-1103. 2001.tb02613.x

Greenwell BM, Boehmke BC, McCarthy AJ (2018) A simple and effective model-based variable importance measure. arXiv Prepr arXiv180504755:1-27

Gronau I, Moran S (2007) Optimal implementations of UPGMA and other common clustering algorithms. Inf Process Lett 104:205210. https://doi.org/10.1016/j.ipl.2007.07.002

Guisan A, Zimmermann NE (2000) Predictive habitat distribution models in ecology. Ecol Modell 135:147-186. https://doi.org/ 10.1016/S0304-3800(00)00354-9

Guisan A, Lehmann A, Ferrier S et al (2006) Making better biogeographical predictions of species' distributions. J Appl Ecol 43:386-392. https://doi.org/10.1111/j.1365-2664.2006.01164.x

Hastie TJ, Tibshirani RJ (1990) Generalized additive models. CRC Press

Hermann RK, Lavender DP (1999) Douglas-fir planted forests. New for 17:53-70. https://doi.org/10.1023/a:1006581028080

Hintsteiner WJ, van Loo M, Neophytou C et al (2018) The geographic origin of old Douglas-fir stands growing in Central Europe. Eur J for Res 137:447-461. https://doi.org/10.1007/ s10342-018-1115-2

Isaac-Renton MG, Roberts DR, Hamann A, Spiecker H (2014) Douglas-fir plantations in Europe: a retrospective test of assisted migration to address climate change. Glob Chang Biol 20:2607-2617. https://doi.org/10.1111/gcb.12604

Isaac-Renton M, Stoehr M, Bealle Statland C, Woods J (2020) Tree breeding and silviculture: Douglas-fir volume gains with minimal wood quality loss under variable planting densities. For Ecol Manage. https://doi.org/10.1016/j.foreco.2020.118094

Jaworski A (2004) Podstawy przyrostowe i ekologiczne odnowienia oraz pielęgnacji drzewostanów. Państwowe Wydawnictwo Rolnicze i Leśne, pp 375

Kawecki TJ, Ebert D (2004) Conceptual issues in local adaptation. Ecol Lett 7:1225-1241. https://doi.org/10.1111/j.1461-0248.2004. 00684.x

Kijowska-Oberc J, Staszak AM, Kamiński J, Ratajczak E (2020) Adaptation of forest trees to rapidly changing climate. Forests 11:1-23. https://doi.org/10.3390/f11020123

Kleinschmit J, Bastien J (1992) IUFRO's role in Douglar-fir (Pseudotsuga menziesii (Mirb.) Franco) tree improvement. Silvae Genet 41:161-173

Kondracki J (2009) Geografia regionalna Polski. Wydawnictwo Naukowe PWN, Third Edition, Warsaw

Konnert M, Bastien J (2020) Genecology of Douglas-fir and tree improvement strategies. EFI What Science can tell us: 46-56

Krakowski J, Stoehr MU (2009) Coastal Douglas-fir provenance variation: patterns and predictions for British Columbia seed transfer. Ann for Sci 66:811-811. https://doi.org/10.1051/forest/2009069

Collins M, Knutti R, Arblaster J, Dufresne J-L, Fichefet T, Friedlingstein P, Gao X, Gutowski WJ, Johns T, Krinner G, Shongwe M, Tebaldi C, Weaver AJ, Wehner MF, Allen MR, Andrews T, Beyerle U, Bitz CM, Bony S, Booth BBB (2013) Long-term Climate Change: Projections, Commitments and Irreversibility. In TF 
Stocker, D Qin, G-K Plattner, MMB Tignor, SK. Allen, J Boschung, A Nauels, Y Xia, V Bex, PM Midgley (Eds.), Climate Change 2013 - The Physical Science Basis: Contribution of Working Group I to the Fifth Assessment Report of the Intergovernmental Panel on Climate Change (pp 1029-1136). (Intergovernmental Panel on Climate Change). Cambridge University Press.

Läderach DP (2011) Predicting the impact of climate change on cashew growing regions in Ghana and Cote d'Ivoire. International Center for Tropical Agriculture (CIAT), Final Report: 1-26

Lavender DP, Hermann RK (2014) Douglas-fir: The genus Pseudotsuga. Oregon Forest Research Laboratory, College of Forestry, Oregon State University, Corvallis, Oregon

Lehmann A, Overton JM, Leathwick JR (2002) GRASP: generalized regression analysis and spatial prediction. Ecol Modell 157:189207. https://doi.org/10.1016/S0304-3800(02)00195-3

Leites LP, Robinson AP, Rehfeldt GE et al (2012) Height-growth response to climatic changes differs among populations of Douglas-fir: a novel analysis of historic data. Ecol Appl 22:154-165. https://doi.org/10.1890/11-0150.1

Matyas C (1994) Modeling climate change effects with provenance test data. Tree Physiol 14:797-804. https://doi.org/10.1093/treep hys/14.7-8-9.797

Mejnartowicz L (1976) Genetic investigations on Douglas-fir (Pseudotsuga menziesii (Mirb.) Franco) populations. Arbor Kórn 21:125-187

Molga M (1986) Meteorologia rolnicza. VII edition. Państwowe Wydawnictwo Rolnicze i Leśne, Warsaw

Näslund M (1936) Skogsförsöksanstaltens gallringsförsök i tallskog. Medd Från Statens Skogsförsöksanstalt 29:1-169

Nathan R, Horvitz N, He Y et al (2011) Spread of North American wind-dispersed trees in future environments. Ecol Lett 14:211219. https://doi.org/10.1111/j.1461-0248.2010.01573.x

Rehfeldt GE (1977) Growth and cold hardiness of intervarietal hybrids of douglas-fir. Theor Appl Genet 50:3-15. https://doi.org/10.1007/ BF00273790

Rehfeldt GE (1989) Ecological adaptations in Douglas-fir (Pseudotsuga menziesii var. glauca): a synthesis. For Ecol Manage 28:203-215

Rehfeldt GE, Leites LP, St Clair JB et al (2014) Comparative genetic responses to climate in the varieties of Pinus ponderosa and Pseudotsuga menziesii: Clines in growth potential. For Ecol Manage 324:138-146
Rousi M, Possen BJHM, Hagqvist R, Thomas BR (2012) From the arctic circle to the canadian prairies a case study of silver birch acclimation capacity. Silva Fenn 46:355-364

Saxe H, Cannell MGR, Johnsen $\varnothing$ et al (2001) Tree and forest functioning in response to global warming. New Phytol 149:369-399. https://doi.org/10.1046/j.1469-8137.2001.00057.x

Schmidtling RC (1994) Use of provenance tests to predict response to climate change: loblolly pine and Norway spruce. Tree Physiol 14:805-817. https://doi.org/10.1093/treephys/14.7-8-9.805

Sit V, Poulin-Costello M (1994) Catalogue of curves for curve fitting. Forest Science Research Branch, Ministry of Forests, pp 110

St Clair JB, Howe GT (2007) Genetic maladaptation of coastal Douglas-fir seedlings to future climates. Glob Chang Biol 13:14411454. https://doi.org/10.1111/j.1365-2486.2007.01385.x

St Clair JB, Mandel NL, Vance-Borland KW (2005) Genecology of Douglas fir in western oregon and Washington. Ann Bot 96:1199_ 1214. https://doi.org/10.1093/aob/mci278

St Clair JB, Howe GT, Kling JG (2020) The 1912 Douglas-fir heredity study: long-term effects of climatic transfer distance on growth and survival. J for 118:1-13. https://doi.org/10.1093/jofore/fvz064

Štrumbelj E, Kononenko I (2014) Explaining prediction models and individual predictions with feature contributions. Knowl Inf Syst 41:647-665. https://doi.org/10.1007/s10115-013-0679-x

van Loo M, Dobrowolska D (2020) Douglas-fir distribution in Europe. Douglas-Fir an Option for Europe EFI What Sci Can Tell Us. 9:21-32

Wang T, Hamann A, Yanchuk A et al (2006) Use of response functions in selecting lodgepole pine populations for future climates. Glob Chang Biol 12:2404-2416. https://doi.org/10.1111/j.1365-2486. 2006.01271.x

Wang T, O'Neill GA, Aitken SN (2010) Integrating environmental and genetic effects to predict responses of tree populations to climate. Ecol Appl 20:153-163. https://doi.org/10.1890/08-2257.1

White TL, Adams WT, Neale DB (2007) Forest genetics. Cabi, Wallingford

Zobel B, Talbert J (1984) Applied forest tree improvement. John Wiley \& Sons, United State

Publisher's Note Springer Nature remains neutral with regard to jurisdictional claims in published maps and institutional affiliations. 